\title{
El protagonista ausente: la aventura literaria de José Antonio Román
}

Gonzalo PORTALS ZUBIATE / Ministerio de Relaciones Exteriores del Perú

\section{Resumen}

¿Se puede ser protagonista desde la sombra? ¿Puede un escritor haber sido tan determinante y sin embargo no haber merecido los reconocimientos de la crítica y el público en su momento? Si bien las respuestas a este par de preguntas son, desde luego, afirmativas, y confirman lo que en muchos otros casos de nuestras literaturas se ha dado de manera sistemática, es más grave aún que, a pesar del tiempo transcurrido, este protagonista continúe a la sombra y/o ausente.

José Antonio Román (Iquique, 1874 - Barcelona, 1920) no solo fue el iniciador de la escuela decadentista en el Perú, sino un importante animador literario desde algunos de los periódicos más influyentes de su tiempo. Además, si hasta hace algún tiempo se pensaba que Clemente Palma ostentaba el privilegio de haber ofrecido el primer volumen de narraciones modernas de sesgo fantástico en nuestro medio, Hojas de mi álbum ', volumen de cuentos de nuestro autor, compite con Cuentos malévolos a la hora de reconocer al antecedente más importante de esta línea creadora.

El siguiente trabajo pretende echar algunas luces sobre la figura de este importante creador peruano, autor de novelas, cuentos, poemas, textos de viajes, crónicas y tesis; y sus repercusiones en la crítica peruana. Además, intentará poner de relieve su condición de forjador de una corriente estilística y ahondará en una serie de consideraciones para confirmar a su libro inicial de cuentos como parte importante de la génesis de todos los esfuerzos futuros en lo que a la tradición fantástica peruana se refiere.

\footnotetext{
R. Velasco, imp. Madrid, 1903, 223 pp.
} 


\section{Palabras clave:}

literatura fantástica, literatura decadentista, narrativa.

\section{Abstract}

This paper presents the figure of José Antonio Román (Iquique, 1874 - Barcelona, 1920) a writer who got to be decisive to our literature as well as unacknowledged in literary circles, and more than that, unrecognized.

The aim of this work is to discuss the major relevance that Román had in relation to the development of peruvian literature and, concretely, to put the stress on his importance as the founder of the Decadentism, as a literary genre in Peru, and also the cardinal role of this writer in relation to the formation of peruvian fantastic literature genre.

\section{Key Words:}

Fantastic literature, decadentism literature, narrative.

"José Antonio Román principió escarabajeando dibujos macábricos de decadentista", dice de nuestro autor Francisco Mostajo en la crítica más antigua que conozco de él, y publicada en uno de los diarios desde donde Román ofreció buena parte de su producción inicial².

Sus primeros cuadros parecen sueños monstruosos de una fantasía enferma. El afán de originalidad le llevó a la senda del extravío. Hoy felizmente ha vuelto al camino real de la Belleza. Sus últimos artículos son deliciosos. Hay en ellos algo de Zola y Flaubert. Junto al rasgo pictórico cautiva la observación psicológica. Entre el Román de las "Japonerías" enrevesadas y el Román de lo "Inevitable" e "Inlunación" el paso es enorme.

En este comentario, el crítico arequipeño hace referencia a la lista más o menos extensa de pequeñas muestras narrativas publicadas por José Antonio Román, fundamentalmente en El Perú Artístico y La Neblina, tales como Japonería ${ }^{3}$; Marina ${ }^{4}$; Mi pantera María ${ }^{5}$; Bajo-relieves ${ }^{6}$; Paisaje $^{7}$; Colibri ${ }^{8}$;

\footnotetext{
${ }^{2}$ La Neblina, Artes y Letras. Lima, Septiembre 16 de 1896. Año I, n 12, 13 y 14. Director, Editor y Propietario: José Santos Chocano.

${ }^{3}$ En: El Perú Artístico, Año II, n² 28, edición correspondiente al 15 de agosto de 1894.

${ }^{4}$ En: El Perú Artístico, Año I, nº 17, correspondiente al $1^{\circ}$ de marzo de 1894, p. 203.

${ }^{5}$ En: El Perú Artístico, Año III, nº 42, correspondiente a la edición del 15 de septiembre de 1895, p. 503; y de La Neblina, Año I, nº 10, del 15 de agosto de 1896, pp. 221-22.

${ }^{6}$ En: El Perú Artístico, Año I, n 23 , edición correspondiente al $1^{\circ}$ de junio de 1894, p. 270.

${ }^{7}$ En: El Perú Artístico, Año I, núm. 13, correspondiente al $1^{\circ}$ de enero de 1894, p. 153.

${ }^{8}$ En: El Perú Artístico, Año I, nº 24, edición correspondiente al 15 de junio de 1894.
} 
Cuento autumnal ${ }^{9}$; La señorita Esther ${ }^{10}$; Flor de loto ${ }^{11}$; Remember ${ }^{12}$; y otros. No comparto, empero, las apreciaciones de Mostajo. Es precisamente en sus textos iniciales donde Román da cuenta de una asimilación mal aprendida y/o peor copiada de los escritores foráneos señalados; y tampoco hay en ellos "dibujos macábricos de decadentista”. Es más bien en los logros posteriores donde nuestro autor consigue empinarse sobre sus deudas estilísticas y obtener resultados más inobjetables, y ahí sí, como señala Mostajo, volver "al camino real de la Belleza", pero a la belleza que es norte y dogma para el ideario de un decadente. Muestras de esta línea inicial de Román lo constituyen los textos Un cuento para Lesbia ${ }^{13}$, y Flor de loto ${ }^{14}$, aparecidos ambos en El Iris. Revista Mensual de Letras, publicación periódica que, junto con otros diarios importantes, se constituyen en las depositarias de los primeros esfuerzos literarios de nuestro autor. Nótese la ornamentación exagerada y la inclinación pronunciada hacia los modos y ambientaciones de tema oriental; los transcribo a continuación:

\section{Un cuento para Lesbia}

En su falda color lila, sedosa y crugiente, vencida, por la fraganciosa pesadumbre de gardenias, daturas y camelias deshojadas, Lesbia cortesana elegante y fastuosa, hunde sus finos y nerviosos dedos buscando el cuento que la noche pasada, extendido á su lado en la chaise-longue, escribí para ella sobre el mullido respaldo.

Y á sus perfumosos pies que calzan exornadas babuchas de corte oriental, en actitud galante y rendida, permanezco yo, mi juvenil rostro reclinado en el tibio y sensual regazo, mientras de sus amplias y transtornadoras pupilas de hetaira romana bajaba hasta las mías insaciable de hermosura al través de sus rútilas pestañas de prolongamiento ideal, su mirada incitante, prometedora...!

Cerca de nosotros el chinero de bruna laca decorado con argénteos enjambres de cigüeñas revoloteando entre dorados lotos, sustenta la pequeña bandeja de metal oxidado. Sobre ella arrojan sus prolongadas sombras sangrientas, las talladas copas plenas de vino.

Por fin descubre, oculto pudorosamente en el amarfilado cáliz de una gardenia, un papelito artísticamente plegado. $Y$ erguido entre sus róseos y triunfales dedos, su satinada blancura emerge claridades de nieve.

\footnotetext{
${ }^{9}$ En: El Perú Artístico, Año I, n² 26, edición correspondiente al 15 de julio de 1894, p. 307.

${ }^{10}$ En: La Neblina, Año II, nº 11 , edición correspondiente al $1^{\circ}$ de septiembre de 1896, pp. 255-6.

${ }^{11}$ En: El Perú Artístico, Año I, n² 22, edición correspondiente al 15 de mayo de 1894, pp. 254-255.

12 En: La Gran Revista, Año I, Núm. 3, edición correspondiente al $1^{\circ}$ de julio de 1897, p. 10.

${ }^{13}$ En la edición de Octubre de 1894, p. 143.

${ }^{14}$ En la edición de abril de 1894.
} 
Lesbia sonriente lee mi cuento. Y cuando concluye, radiante de alegría, me tiende ansiosa sus amorosos brazos de Venus Anadyomena...!

\section{Flor de loto}

\section{A Angélica Palma}

¡Amarfilda flor de loto que aroma el vimana de la sacra pagoda! Te dedica sus más castos pensamientos en la callada y misteriosa nocturnancia el pálido bonzo de albo sayal, mientras en las floridas márgenes del sagrado río, batiendo convulsamente los sonantes élictros, entonan los noctámbulos insectos exótica fanfarria.

En tus místicos ensueños te vislumbra lucífera el patriarcal brachma idólatra de enigmáticos avatares. Sigue la vírgen indiana con la mirada tus temblequeos pudorosos sobre el haz de las estancadas linfas, y explendes ahí como blanca estrella zozobrante!...

Ensombrecidos y nostálgicos los jóvenes poetas indios te han diseñado en sus versos melancólicos y sufrientes. Tu imagen, célica y nimbosa, les sirve de portaestandarte en sus luchas con los despiadados raxasas, que diabliposas llevan como funerarias antorchas en sus malévolas incursiones a las erráticas noctílucas.

Tienes en tus núbiles mejillas el delicado matiz del rosado loto que se pincela nimiamente sobre el glauco y movible lienzo del lago, en tanto que los bambúes marginales, grandiosos y verdes abanicos, refrescan en su bamboleo el ambiente y apenumbran las satinadas y flébiles corolas.

En tus vírgenes pupilas flotan sombras de santuarios clausurados y misteriosos; hay en ellas revoloteadoras plegarias que sólo esperan tu mandato para, desplegando las eucarísticas alas, volar al cielo, la patria azul. En tu perfil de régia adalid, en tu recogida cabellera como casco de invencible y seductora amazona, brillan las indomiteces y altanerías de las que rigen vastos imperios.

Sin embargo cualquiera, al verte tan grácil, flexible y casi alada, piensa en las indostanas bayaderas que vestidas de polícroma nerinda y agitándose en danzas sagradas hacen tintinabulear monorítmicamente los broncíneos talus, mientras de tus sienes diademazas de cándidos nenúfares emergen lampos prístinos y diamantinos. Y Kalí, la bella diosa, tremolando su diáfano velo rosa tramado de argénteos hilos, parece ofrendarles un ramo de sus litúrgicas y bien amadas flores...!

¡Oh mi pálida princesa indiana, te veo montada sobre pieles valiosas, taloneando con dorados espolines las sedosas ancas de blanco y mitológico unicornio!

¡Te sueño en bizarro palanquín construido de bruñido marfil, constelado de rara pedrería, y llevada lentamente en magna procesión, por el tardo y ceremonioso paso de los grises y gigantescos cuadrúpedos! 
Cuando yo sea radjá de vastas tierras y miles de esclavos obedezcan temblantes mis órdenes; cuando pasée las calles de mi ciudad en pompa magnífica, blandamente arrastrado en suntuoso carro triunfal doselado de riquísimos chales pérsicos; entonces, muy junto a mí, entre jocundos vítores de mis vasallos, tendrás tu sitio, ¡oh mi pálida princesa indiana!

El mismo Mostajo, en su tesis de 1896, El Modernismo y el Americanismo, para optar el Grado de Bachiller en la Facultad de Filosofía y Letras de la Universidad de San Agustín de Arequipa ${ }^{15}$, había hecho esta referencia de nuestro autor:

Los modernistas limenses, como propulsores que fueron de la innovación, avanzaron más allá del punto de mira, hasta enredarse muchas veces en la maraña de lo exagerado. Pero en un principio, el decadentismo los deslumbró con sus figuraciones de sol moribundo. Y Chocano i Fiansón i Román quemaron inciensos en las arias de Mallarmé. Apenas Arnao Concha i Astete i Palma se preservaron del fascinamiento. El primero siguió con paso firme las huellas de Zola i el segundo algo miedoso, se acompañó en el camino con Daudet, ese buen camarada. En cuanto a Palma si marcha por la misma ruta, lo hace distraídamente, volviendo los ojos a cada rato hacia las frondosidades modernistas. La decadencia en Lima, lo mismo que en las demás capitales americanas, pasó felizmente rápido como una aurora ó como un crepúsculo. Pronto llegó, pues, la calma i la miríada juvenil se entró en rondón por la puerta del modernismo. (38-39)

En esta tesis, un joven Mostajo, dotado de un buen juicio crítico y al tanto del movimiento literario hispanoamericano, se permite establecer los vasos comunicantes entre el movimiento modernista y el ideal del americanismo.

Dos órdenes de factores confluyen evidentemente en el origen de esta tesis [señala sobre el particular Jorge Cornejo Polar ${ }^{16}$ ] La presencia en el mundo literario hispanoamericano del modernismo en la fase ascendente de su esplendor, es, sin duda, una de sus motivaciones. La otra nace de la inquietud existente en el Perú y en el resto de América Latina en torno a lo que debería ser una literatura auténticamente americana. La búsqueda del 'americanismo literario', como se solía decir entonces, era la voz de orden en nuestro mundo intelectual en el tercio final de la centuria decimonónica. (12)

\footnotetext{
${ }^{15}$ En: Francisco Mostajo. Antología de su Obra. Arequipa: Cervecería del Sur, 2002.

${ }^{16}$ Op. Cit.
} 
Conviene recordar que la caracterización del período modernista que establece el historiador, jurista, crítico literario, poeta y periodista arequipeño es casi la misma que elaboró la crítica durante el siglo XX. Además, su tesis resulta doblemente significativa en la medida en que aparece seis años después de la publicación de Azul de Rubén Darío, texto que definió el momento inicial del modernismo.

Mostajo se pronuncia finalmente -y luego de amplia argumentación[dice Cornejo Polar] por el modernismo como el mejor medio de llegar al ideal de una literatura hispanoamericana estéticamente válida y, a la vez, autónoma. Dice: "(el modernismo) nos conducirá a la emancipación con el gran principio del individualismo artístico que proclama". (13)

Pero no será sino hasta dos décadas después cuando una impresión fotográfica de nuestro autor, refrendada por un texto breve, nos aproximará a un Román siempre evasivo y trashumante. Bajo el título "De la antigua bohemia. Una fotografía histórica"17, se publica una imagen en la que aparecen, además de él, Luis Aurelio Loayza, Manuel Moncloa y Covarrubias, José Santos Chocano y José Fiansón. La leyenda dice:

No deja de ser interesante la fotografía que publicamos en esta página, en la cual aparecen varios literatos nacionales, todos ellos esforzados cultivadores de las Bellas Letras. Solamente uno, don Manuel Moncloa y Covarrubias, regocijado autor de El Teatro en Lima y Lima por dentro ha fallecido". (...) "Este grupo de intelectuales", se añade en la reseña, "data del año 1897 (Román ostentaba 23 años [la cita es mía]) y fue tomada en la sala de redacción de la antigua Imprenta del Estado, cuando estuvo ubicada en la calle de la Rifa. En tiempos del presidente coronel Remigio Morales Bermúdez, en ese mismo local se editó el antiguo periódico 'El Diario'. Figuran en el referido grupo: José Santos Chocano, nuestro gran poeta; José Fiansón, que hoy ejerce en Chosica una judicatura de paz; Luis Alberto Loayza (sic), aplaudido escritor de costumbres y José Antonio Román, brillante literato y abogado, actualmente en Iquique, autor de "Hojas de mi álbum" y "Almas Inquietas", obras publicadas en España. (35)

Dos años más tarde, una nueva imagen del recuerdo, aparecida en una publicación mensual ${ }^{18}$, vuelve a darnos cuenta de un Román casi desapercibido en medio de una discusión académica al interior del claustro universitario. La leyenda de la imagen reza así:

\footnotetext{
${ }^{17}$ En: Sudamérica, Año I, N 1, del 22 de diciembre de 1917.

${ }^{18}$ Studium, tomo I, Año I, No. 1, de diciembre MCMXIX.
} 
Alumnos de Derecho Penal discutiendo en vísperas de examen, el "ancestral" problema de la pena de muerte. (En primer término y de izquierda a derecha los señores Juan Manuel Peña y Prado, Hernán Monzante y Héctor Morey; en segundo término José Vila y Acuña; y en tercero, Enrique Baglietto, Ricardo de la Puente y Ganoza y J.A. Román. (98)

En 1920, en el voluminoso repaso a la lengua y la literatura castellanas hecho por Cejador ${ }^{19}$, hay una pequeña pero interesante apuntación sobre nuestro autor que dice así:

JOSÉ ANTONIO ROMÁN (N. 1873), de Iquique (Chile), abogado, que viajó mucho y es narrador de paleta colorista é imaginación viva, algo inclinado a lo ideal y soñador, sin dejar por eso de ser realista. Publicó Hojas de mi álbum, cuentos, Madrid, 1903. Almas inquietas, 1915. Sensaciones de Oriente, 1917. Fracaso, nov. Peruana, Barcelona, 1919. (114)

La nota de Cejador sería reproducida, medio siglo más tarde, por la Enciclopedia Universal Ilustrada Europeo-Americana ${ }^{20}$, en su tomo LII.

Sin embargo, con el paso del tiempo y la desaparición física de nuestro autor, la crítica no volvería a ocuparse de Román sino hasta 1950, fecha en la que el connotado crítico Alberto Tauro del Pino lo despercude oportunamente en un artículo ${ }^{21}$ en el que, además, incluye Los hipocampos (prosa y verso); La venganza de Diana (prosa, fechada en Lima el 14 de enero de 1897; y verso, fechado en Lima en 1898); En el Nilo (prosa); y El muelle viejo (prosa, fechado en Lima en 1897; y verso).

Visos de tragedia", señala Tauro, "presenta el caso literario de José Antonio Román, quien a fines del siglo XIX parecía imponer orientaciones al desenvolvimiento de la prosa narrativa en tanto que José Santos Chocano empezaba a señorear en la poesía, y hoy carece de lugar en las antologías y las reseñas que afectan a las letras peruanas de aquellos días. Aún más, su silueta y la memoria de su peripecia personal se hallan trasegadas y casi sumidas en el olvido. Pero no se crea que así ha dictaminado la posteridad acerca de los méritos de su obra. Así se ha cumplido el sino que persigue a la cultura en el exilio, pues José Antonio Román no quiso aceptar la nacionalidad que su tierra nativa adquirió debido a la infausta Guerra

\footnotetext{
${ }_{19}$ Cejador y Frauca, Julio. Historia de la lengua y literatura castellana 1915-1922, comprendidos los autores hispano-americanos. Madrid: Revista de Archivos, Bibliotecas y Museos, 1929, tomo XII.

${ }^{20}$ Madrid: Espasa-Calpe, S.A., 1979.

${ }^{21}$ En: La Hora del Hombre, edición correspondiente a la segunda época, Año I (6) - n 4 (69), de los meses julio-septiembre de 1950, pp. 11 - 14.
} 
del Pacífico, porque su sentimiento y su conducta lo inclinaban a demostrar simpatía por el Perú, en la apartada población donde la violencia cambiaba la faz de las cosas; $y$, desarraigado de aquel suelo entrañable, fué un pertinaz trotamundos, un viajero que en países exóticos buscó solaz a su curiosidad y su indudable desadaptación, un emigrado. (11)

Tauro nos acerca a la figura no solo literaria del autor, sino también humana, cuando añade:

José Antonio Román -hijo de un salitrero del mismo nombre, y de María Rosado- nació en Iquique, el año 1874. Después de cursar los estudios elementales trasladóse (1888) a Lima donde habitó una vieja casona situada en la Plazuela de la Inquisición, y signada entonces con el No. 97. En 1892 ingresó a la Facultad de Letras de la Universidad Mayor de San Marcos, en la cual optó, sucesivamente, los grados de Bachiller y Doctor: el primero (12 de octubre de 1894), con una tesis sobre la pintura japonesa; y el segundo (26 de setiembre de 1895), con una sugestiva exégesis de Enrique Ibsen y su teatro, honrada con la inserción en los Anales Universitarios. Simultáneamente, había hecho estudio en la Facultad de Jurisprudencia y en la Facultad de Ciencias Políticas y Administrativas. En la primera obtuvo el grado de Bachiller (1896) con una novedosa disertación sobre El contagio del crimen, y, dos años más tarde, el título de abogado; y a la segunda presentó (1898) dos tesis de inspiración renovadora, sobre El impuesto progresivo y El lujo como materia imposible, para optar los grados de Bachiller y Doctor respectivamente. Bien podía calificarlo Domingo Martínez Luján como "tres veces doctor y docto una vez por todas". (...) Ya había irrumpido en los círculos literarios de Lima, con juvenil beligerancia", añade el crítico chalaco, "y, desde las páginas de La Opinión Nacional enaltecía la obligación de imprimir calidad estética al estilo, aunque ello contrariase los gustos vulgares. Desacreditaba las convencionales lamentaciones del romanticismo, así como el dócil sometimiento a los preceptos de la retórica; y, consecuentemente, declaraba que sólo escribía por satisfacer un íntimo deseo, sobre aquello que su voluntad y su emoción le dictasen. Se explica que hacia él se proyectasen los tiros de algún desconcertado seguidor de viejos rumbos (en Neblina, 12 de enero de 1895, bajo el seudónimo de "Fernando Fierro Fernández"):

Ese decadente empeño

y ese arte japonés, 
¿no ves, Antonio, no ves,

que carga, aburre y da sueño?

Deja al fin la decadencia

y no escribas... candideces;

pues hace ya muchos meses

que nos... mueles la presencia. (11)

Muestra de ese "empeño" y "arte japonés", que nuestro autor no abandonaría fácilmente -su tesis para optar el Grado de Bachiller por la Facultad de Letras de la Universidad Nacional Mayor de San Marcos 22 aborda precisamente esa materia-, lo constituye este pequeño texto, que seguramente fue uno de los que encendió buena parte de la crítica antes mencionada.

\section{Japonerías ${ }^{23}$}

Kami, la bella hija de Kyoto, cortesana inspiradora de los poetas nipones, yace sobre la lustrosa estera reclinada sobre amarillos cojines, teniendo a su lado un braserillo de tintes brunos, franjeado de oro y simulando un gato en soñoliento reposo. La luz de la lámpara, fina obra de orfebrería, se quiebra gozosa y rielante en el cobre del artefacto, de donde, vaporosas, y de contornos tembladores, se escapan ondas azuladas y perfumosas.

Sobre mesita de ébano chapeada de laca con esmaltes de nácar en forma de lotos y paulouinias humean las tazas aromatizadoras, y en su fondo que el artífice japonés decoró lozano y fantasista las hojitas de té distienden infusionadas sus pliegues ensoñadores.

Mancha el amplio testero, blanco y pulido, como que está hecho de papel de arroz, una máscara de madera representando a la vieja poetisa Komati con sus facciones exangües, momificadas, pintando su existencia hambreada.

De su obbi, gracioso cinturón que oprime delicadamente su torso de guecha, pende un artístico netzké de marfil coloreado debido al célebre Ikkó, donde en lindo claro de luna vense monos rampantes que devoran dorados frutos de Kaki.

¡Kami semivelada por las nefelorides volutas de su pipa, agitando melancólicamente su monumental peinado, clama lírica y gimiente por Teisái el colorista delicioso y original, el de tonos sublimes y libélulas sedosas y vibrantes...!

\footnotetext{
22 "La pintura japonesa". Lima, s/n, 1894.

${ }^{23}$ En: El Perú Artístico, Año II, núm. 28, edición correspondiente al 15 de agosto de 1894.
} 
Y se comprende [continúa señalando Tauro] que, al optar el grado de doctor en la Facultad de Letras, el catedrático de Estética le hubiese pedido que expusiera la teoría del arte decadente. Por la altivez y la resonancia de su actitud, José Antonio Román era el jefe de las tendencias decadentistas. (...) Después de diez años de ausencia [prosigue Tauro] volvió [nuestro autor], en 1898, a Iquique. Pero su devoción y su simpatía lo vinculaban al Perú, y percibió nítidamente que era un extraño en aquella tierra. No tardó en retornar a Lima, hostigado por intensa ansia de saciar sus angustias en largos peregrinajes. Inició una vuelta al mundo, de la cual retornó en 1905. Ejerció su profesión de abogado, en Lima; e intentó hacer lo mismo en Iquique (1917) donde sus sentimientos peruanistas lo hicieron merecer una recia golpeadura y un involuntario baño de mar. Pasó a Brasil y luego a España. Murió en Barcelona, durante el cálido mes de julio del año 1920. [Y concluye apuntando:] José Antonio Román publicó Enrique Ibsen y su teatro (Lima, 1895), Páginas de mi álbum (Madrid, 1903), Sensaciones de Oriente (Barcelona, 1917) y Fracaso (Barcelona, 1918). (11)

Si bien Tauro obvia Almas inquietas, volumen que reúne tres cuentos y una novela corta, nos ofrece la muestra más exhaustiva hecha de nuestro autor hasta esa fecha. A los cuentos breves anotados anteriormente, durante el período que media entre 1893 y 1901, José Antonio Román dio a la luz otro manojo de narraciones algo más extensas. Muchas de estas no serían incluidas en su volumen de 1903, pero irían consolidando una prosa cuyos resultados y méritos resultan visibles en ése y volúmenes ulteriores. Es el caso, por ejemplo, de Pierrot borracho ${ }^{24}$; Santerre ${ }^{25}$; El beso de la estrella ${ }^{26}$; Cuadro bíblico ${ }^{27}$; La tentación de un trapense ${ }^{28}$; Infidelidad ${ }^{29}$; o Lo inevitable ${ }^{30}$. Existen, además, otros dos cuentos que por probables erratas a la hora de consignar el nombre del autor, no me animo a adjudicárselos plenamente, pero que por los rasgos estilísticos empleados, podrían asumirse suyos; tal es el caso de Souviens-toi! ${ }^{31}$,

\footnotetext{
${ }^{24}$ En: El Modernismo, edición del 16 de diciembre de 1900, pp. 22-23.

${ }^{25}$ En. El Modernismo, edición del 30 de diciembre de 1900, pp. 44-45.

${ }^{26}$ Aunque fechado en 1894, se publicó en La Neblina, Artes y Letras, Año I, $\mathrm{n}^{\circ} 1$, correspondiente al 20 de marzo de 1896, pp. 16-17. Director, Editor y Propietario: José Santos Chocano.

${ }^{27}$ En: La Gran Revista, Año I, Núm. 6, edición correspondiente al 16 de agosto de 1897, pp. 5-6.

${ }^{28}$ En: El Modernismo, correspondiente al 13 de enero de 1901, pp. 67-68; y 20 de enero del mismo año, p. 83.

${ }^{29}$ En: La Gran Revista, Año I, Núm. 3, edición correspondiente al $1^{\circ}$ de julio de 1897, pp. 4-5.

${ }^{30}$ En: La Neblina, Año I, n² 2, correspondiente al 5 de abril de 1896, pp. 27-28.

${ }^{31}$ En: El Perú Artístico, Año III, núm. 40, del 15 de agosto de 1895, p. 477.
} 
firmado por Pedro Antonio Román; y Cliché ${ }^{32}$, firmado de manera lacónica por José Antonio.

Pero no será sino hasta una década después de lo apuntado por Tauro del Pino, que otro crítico literario, Alberto Escobar, en su reconocido volumen dedicado a la prosa peruana ${ }^{33}$, al tiempo de incluir el texto El muelle viejo, diga de nuestro autor:

José Antonio Román (n. Iquique, 1874 - Barcelona, 1920). Estudió en las Facultades de Letras, Derecho y Ciencias Políticas de la Universidad de San Marcos. Sufrió intensamente el desarraigo, a causa de la incorporación de su ciudad natal a Chile; pero tampoco residió permanentemente en Lima, pues tuvo la pasión de los viajes. Emprendió una vuelta al mundo, de la cual retornó en 1905. Más adelante se trasladó al Brasil y luego a España, en donde falleció. Su obra es casi desconocida en el Perú, no obstante ser de los iniciadores del modernismo en prosa y poesía. (...) Colaboró en La Neblina con el seudónimo de Fernando Fierro Fernández. [sic] (171)

Próxima en fecha a la cita anteriormente expuesta, Estuardo Núñez, en un texto que pretende ofrecer un panorama general de la literatura peruana durante el siglo anterior ${ }^{34}$, hace referencia al período modernista en general y a nuestro autor en particular, en los siguientes términos:

Se ha subestimado un tanto la proyección del movimiento llamado Modernismo sobre la poesía hispanoamericana. Se le ha presentado como una escuela esencialmente poética, encumbrándose a su principal gestor Rubén Darío. La crítica más reciente y los análisis de estilo más rigurosos han llevado a establecer la existencia de este movimiento de valiosos narradores, antes poco conocidos o poco estimados. Del examen de los cuentos modernistas del Perú no podría prescindir quien quiera encontrar las raíces y simientes de donde ha surgido la frondosa, variable y dispar producción narrativa de los últimos decenios. (71)

Apunta que se dejaron de lado

otros nombres de autores que muchas veces no llegaron a editar el volumen definitivo aunque dejaron importante obra dispersa en periódicos y revistas. [Y reconoce que resulta imprescindible] consignar los nombres de una generación muy pródiga aunque tal vez poco organizada: Aurelio Arnao (1872-1940), Jorge Miota (1870-

\footnotetext{
32 En: El Perú Artístico, Año I, núm. 10, del 15 de noviembre y $1^{\circ}$ de diciembre de 1893.

${ }^{33}$ La narración en el Perú. Estudio preliminar, antología y notas. Lima, Editorial Juan Mejía Baca, 1960.

${ }^{34}$ La literatura peruana en el siglo XX. Lima, 1963. México: Editorial Pomaca, S.A. de C.V., 1965.
} 
1926), José Antonio Román (1874-1920), José Félix de la Puente (1882-1959), Amalia Puga de Losada (1866-1962), Juan Manuel Polar (1868-1936), Augusto Aguirre Morales (1888-1917), Juan Manuel Osorio, Carlos E. B. Ledgard (1877-1953; Ensueños -cuentos, Iquique, 1899), Raymundo Morales de la Torre (1885-1936), Carlos Camino Calderón (1884-1956), Luis Esteves Chacaltana, Federico Blume (1863-1936), Zoila Aurora Cáceres (1880-1959; Las perlas de Rosa, París, 1910?, La princesa Suma Tica "narraciones peruanas", Madrid, 1929), José M. Tapia y otros autores menores. (71-72)

$Y$ tras sindicar al hijo de nuestro insigne tradicionista como el iniciador de la literatura fantástica en el Perú, añade de nuestro autor lo siguiente:

José Antonio Román, Manuel A. San Juan, Alberto Salomón dejaron rastros en periódicos de fines del siglo XIX y comienzos del XX, de su dedicación al comentario crítico de la literatura francesa y nacional, mas no persistieron en ese empeño. (160)

En 1966, en su Diccionario manual de literatura peruana y materias afines ${ }^{35}$, Emilia Romero de Valle da cuenta de los detalles bio-bibliográficos ya conocidos de nuestro autor, pues cita como referencias inmediatas las de Alberto Tauro de Hora del hombre y La narración en el Perú de Alberto Escobar.

Otro investigador, Maurilio Arriola Grande, en su nomenclatura por autores ${ }^{36}$ de fines de la década del 60, hace casi lo mismo, aunque añade de Román una página de El muelle viejo:

Es en mi país de penosos recuerdos y vagos ensueños donde está el muelle viejo. Arriba un cielo de brumas, misterioso, que pone dulce melancolía en las almas tristes. Abajo, dilatándose hasta lejanos horizontes, un mar estañado, soñoliento, choca rudamente contra las grises rocas, rajadas por el tiempo, mordidas por las olas. Allá, en el solitario extremo de aquella abrupta playa, se alza el antiguo muelle, eternamente batido por los temporales, siempre azotado por los huracanes. Ya sea que la jubilosa aurora prenda racimos de fulgentes brillantes en los exornativos líquenes de sus destruidas pilastras, o que al declinar el día, entre los radiosos destellos del moribundo sol se ilumine con una suave claridad de oro demasiado tenue, siempre tiene para mí esa indefinible poesía de las cosas viejas. En las tardes de otoño, cuando hay mucha bruma en el ambiente y mucha tristeza en el fondo del alma mía, me dirijo allí, donde están esas queridas

\footnotetext{
${ }^{35}$ Editado en los Talleres de la Imprenta de la Universidad Nacional, 1966.

${ }^{36}$ Diccionario Literario del Perú. Comercial y Artes Gráficas, S. A. Barcelona, 1968.
} 
reliquias, constantemente salpicadas por las turbulentas ondas... Las aguas se recogen y se hinchan, preparándose, mugiendo sordamente. Luego todo aquel inmenso vientre se agrieta y las olas altísimas, tumultuosas, se abalanzan unas tras otras, rebramadoras, sobre los ruinosos muros. Los cubren hasta el ápice; después, exhaustas, se tienden desmayadas, blancas de hervorosas espumas. Alguna logra pasar por entre los claros de la columnata y sigue bulliciosa su camino, lanzando a los aires un rugido de triunfo. Y vuelven con ensordecedor estrépito, en furioso y precipitado galope, a sucederse las olas indomables, porfiadas en la lucha; porque el mar al retirarse ha visto que su adversario ha resurgido completamente lavado, dejando escurrir por sus aristas diamantinos chorros.... (433)

De ese mismo año data una misiva de Adalberto Varallanos ${ }^{37}$, en la que el autor huanuqueño hace referencia a unas muestras antológicas de poesía y cuento, preparadas por él, que la prestigiosa editorial Maucci de España publicaría, como efectivamente así le responden los dueños de la casa hispana. La carta, fechada el 21 de noviembre de 1928, y dirigida al Director de La Prensa, dice a la letra lo siguiente:

Muy digno señor. Quiero informar a Ud. y por su intermedio al público, la próxima aparición de dos libros peruanos de determinado interés literario: una ANTOLOCÍA DE LA POESÍA PERUANA (18951928) y ANTOLOGÍA DE CUENTISTAS PERUANOS (1895-1928). Por recomendación exprofesa de un crítico francés y a propuesta mía, la Casa Editorial Maucci, de Barcelona, y la Agencia Mundial de Librería de París, las editan y encargan de hacerlas circular por el continente. (266)

Continúa en estos términos:

Estimando peligroso, desde luego, no tan solo por la autoridad crítico-artística de que debe estar investido el autor -que no es un mero coleccionista- que salta de inmediato al juicio particular; sino más bien al carácter o particularidad de la misma que pretende tener en relación a las anteriores. Se ha tenido en cuenta, y sin que esto no sea una superación, las colecciones de Ventura García Calderón (Barcelona y París, 1910) y la colección de D. Manuel Beltroy (Lima, 1921), las únicas. (...) Descontada la definición que de las antologías se pretendiera dar, dentro del mediano conjunto que se presenta y la pequeñez de la lírica peruana; en cada autor se ha tenido en cuenta, primordialmente, los valores artísticos. Teniendo del arte un criterio progresivo, los accidentes históricos, anecdóticos y otras circunstancias han quedado relegados. (266)

\footnotetext{
${ }^{37}$ En: Permanencia. Cuentos, poemas, crítica y otros escritos. Ediciones Andimar. Buenos Aires, 1968.
} 
Y tras referirse a las consideraciones para la elaboración de la antología poética y consignar los nombres a incluir, continúa de este modo:

La selección de cuentos, con un estudio sobre el proceso del cuento en el Perú, incluye a los siguientes: Ricardo Palma, Abraham Valdelomar, E. López Albújar, V. García Calderón, César Vallejo, Luis E. Valcárcel, Manuel Beingolea, A. Aguirre Morales, J. A. Román, Clemente Palma, Jorge Guillermo Escobar, Héctor Velarde Vergman, Alberto Hidalgo, A. Garland, Martín Adán, J. Castillo Báltico, Gamaliel Churata, José María Arguedas, P. Barrantes Castro, Fernando Romero, Aurelio Arnao, José Diez Canseco, Carlos Gabriel Saco. (267)

Varallanos concluye su misiva de la siguiente manera:

Mi interés de poner en conocimiento del público, se debe a que, como es frecuente, alguien pueda adjudicarse la iniciativa, sin que esto quiera significar que cualquiera -en último extremo- no esté facultado a publicar libros semejantes. (En América creo que todavía no hay propiedad de ideas ni de iniciativas literarias, que en Europa existe). $O$ sucede que, a veces, se incurre en forzadas coincidencias y hasta con identidad de ideas por parte de intelectuales apresurados, como tengo mis sospechas. (267)

Desconozco si el proyecto del joven Varallanos fue coronado con éxito, vale decir si la reconocida casa Maucci publicó los volúmenes o si los mismos fueron ofrecidos a otra casa editora. De haber ocurrido así, ésta hubiera sido la única muestra antológica reconocedora de las bondades cuentísticas de nuestro autor hecha en vida, y, desde luego, una nueva muestra de la perspicacia y el innegable talento del autor de Receptáculo de términos.

Por otro lado, Luis Alberto Sánchez, en su visión general del proceso literario peruano ${ }^{38}$, refiriéndose a la égida ejercida por José Santos Chocano hacia fines del siglo XIX y a los grupos literarios establecidos durante esa época, señala:

Uno de estos grupos se llamó Enrique Alvarado, del nombre de un joven intelectual de la generación romántica, que no produjo libro alguno, pero a quien unánimemente reconocían sus contemporáneos, singularísimas dotes de generosidad, estudio y ponderación. La presidencia se hizo rotativa, por orden alfabético. La ejercieron, entre otros, Chocano, José Augusto de Izcue, Jerónimo de Lama y Ossa, Juan Francisco Pazos Varela, Germán Arenas, Carlos Ismael Lisson, Enrique

\footnotetext{
${ }^{38}$ La literatura peruana. Derrotero para una Historia Cultural del Perú. P. L. Villanueva Editor, 1966, tomos III y IV.
} 
A. Carrillo, Ernesto Boza, Luis Rospigliosi y Vigil. De todos ellos, sólo Chocano y Carrillo, el benjamín, fueron fieles a la literatura. Izcue lo fué en cierta medida. Los demás emigraron pronto a campos mejor rentados. (1133)

Sánchez prosigue así:

Otro grupo llevó el nombre de 'Pablo de Olavide'. En él se reunían Domingo Martínez Luján, Enrique Castro Oyanguren y, hasta donde me es posible aseverarlo, Clemente Palma, José Fiansón y Federico Larrañaga. Sin duda, todos ellos descollaron en las letras, a las que guardaron irrecusable lealtad. [Y sigue:] En 1896, comienza (Chocano) la publicación de La Neblina, quincenario de arte y letras, que dura hasta 1897. Chocano lo dirige y administra. En sus páginas se inicia Florentino Alcorta, con unos armoniosos versos "A la campiña"; José Fiansón; Clemente Palma; Enrique A. Carrillo (de veinte años); Alberto Salomón; Enrique López Albújar; y se consagran José Antonio Román, José M. Tapia, Francisco Mostajo, Federico Larrañaga. (1134)

Páginas más adelante, el escritor y crítico limeño cierra su comentario centrándose un poco más en la figura de nuestro autor:

La crítica no ha querido detenerse en José Antonio Román (Iquique, 1874- Barcelona, 1920), [dice] autor de Páginas de mi álbum (Madrid, 1903), Almas inquietas (Barcelona, 1916), Sensaciones de Oriente (1917), Fracaso (Barcelona, 1919), libros dignos de memoria, por su corrección y hasta por su valentía. Román, como M Molina y V Mantilla, nació en la zona ocupada desde 1879 por Chile, y gran parte de su incógnita existencia transcurrió en viajes a remotos parajes y en una larga permanencia en Madrid. Alejado del centro de actividades literarias, o sea, de Lima, su voz encontraba eco remiso entre los críticos. En "La Neblina" publicó (1896) varios relatos, en todos los cuales se pone en evidencia su amor al verismo naturalista. La misma circunstancia de sus andanzas le permitieron abrir sus horizontes espirituales y ensayar modos inéditos en Perú. "Fracaso" es, sin duda, una novela interesante, aunque un tanto desmañada en la forma, como que Román trataba de mantenerse fiel al módulo naturalismo ya en crisis. "Visiones de Oriente" [sic] incorpora un tema nuevo, pues casi siempre fué explorado en teoría, no en la práctica, en nuestras letras. (1216)

Años más tarde, el crítico Ricardo González Vigil, en su primer volumen antológico dedicado al cuento peruano ${ }^{39}$, vuelve a valorar el trabajo de José Antonio Román, e incluye su cuento El beso de Elvira. Sus comentarios ahondan en las bondades de nuestro autor de esta manera:

\footnotetext{
${ }^{39}$ El cuento peruano hasta 1919. Lima: Ediciones Copé, 1992.
} 
Ya es hora de rendir justicia a los méritos literarios de José Antonio Román (Iquique, 1874 - Barcelona, 1920). Consterna sobremanera constatar que hace cuatro décadas Alberto Tauro instó a dicho rescate, y hasta ahora permanece pendiente". Y citando un párrafo del comentario que Tauro del Pino le deparó a Román en su oportunidad, R.G.V. añade: "Es cierto que Luis Alberto Sánchez lo menciona, pero sólo de paso, dejando al lector la impresión de que constituye una figura muy secundaria de fines del XIX y comienzos del XX, cuando la verdad es que Román es un cuentista descollante entre nuestros modernistas, tan valioso o más que otros que han tenido mejor fortuna que él, un Clemente Palma o un Manuel Beingolea (entre otros géneros, Román fue un poeta parnasiano de interés y un fino tejedor de estampas poéticas en prosa). Además, Sánchez lo caracteriza impropiamente como autor "naturalista"; Román era, más bien, un "decadentista" con algunos rasgos parnasianos y otros impresionistas, es decir, un modernista cabal, de los más representativos en la narrativa peruana. (670)

Y continúa en esta línea:

De otro lado, es cierto que las antologías de Estuardo Núñez y Alberto Escobar le conceden atención, pero no logran reflejar adecuadamente su talla de cuentista, ya sea porque Núñez extrae un fragmento (de poca cohesión narrativa) de la novela corta "El cuaderno azul" (incluida en Almas inquietas), ya sea porque Escobar selecciona una prosa evocativa de tono lírico ("El muelle viejo", sintomáticamente Román compuso también un soneto sobre el mismo tema, prosa poética y soneto reunidos por Alberto Tauro en su aporte de 1959). (670-671)

En efecto, el soneto mencionado ${ }^{40}$ es una composición llena de misterio, que habla del espíritu pertinaz de una construcción marina negada a sucumbir. Signo del tránsito de un siglo a otro, la representación de un muelle antiguo da lugar a una serie de lecturas subalternas; lo transcribo a continuación:

\section{El muelle viejo}

Sobre un peñón brumoso y solitario,

El viejo muelle en el confín violeta

Esquicia entre las rocas su silueta

Como un doliente espectro legendario;

\footnotetext{
${ }^{40}$ En: El Modernismo, Literatura y Arte. Lima, 20 de enero de 1901, № 7.
} 


\begin{abstract}
A sus pies estañado, tumultuario,
El mar rebrumador se hincha y agrieta,

$Y$ del agua la tromba cual saeta

Se estrella desgranando su rosario.

Pero es vano el furor del oleaje

Que viste al muelle con un blanco traje;

Porque entre algas y líquenes y hiedras,

Que exornan mustios las rajadas piedras,

De un ocaso de púrpura al reflejo,

Resurge pertinaz el muelle viejo.
\end{abstract}

\title{
González Vigil considera que
}

conforme ha investigado Tauro, Román fue uno de los escritores que en Lima con más nitidez, en la última década del siglo XIX (desde La Neblina y La Opinión Nacional), asumieron las sendas innovadoras del Modernismo. [Y rescata la frase más sugerente de Tauro:] Por la altivez y la resonancia de su actitud, José Antonio Román era el jefe de las tendencias decadentistas. (671)

Además añade que nuestro autor,

nacido en lquique, se formó en Lima, donde hizo sus estudios secundarios y universitarios, integrándose después a la vida literaria de entonces. $Y$ aunque retornó en dos breves ocasiones a Iquique (señalemos, de paso, que viajó mucho por diversas regiones del planeta), no respaldó la chilenización de su suelo natal, sintiéndose siempre peruano. En 1919, fue acusado en Iquique de espía y conspirador, sufriendo una golpeadura y un prolongado baño de mar. (671);

para finalizar con estas caracterizaciones:

Más diestro para el texto corto que para el largo, las piezas memorables de Román se encuentran en Hojas de mi álbum (título que aprovecha la cercanía fónica entre árbol y álbum y la polisemia de hojas): estampas o viñetas que recrean momentos decisivos de la pasión (voluptuosa, ciega) de Marco Antonio por Cleopatra, Salomón por la reina de Saba y Alejandro por Thais; cuentos de seres fantásticos (ondinas, hipocampos, etc)., cuentos ambientados en ciudades del presente (hay muchos pasajes dedicados a Lima) con penetrantes 
análisis psicológicos de la pasión erótica y la atracción ejercida por el vicio; y cuentos de terror y locura, fuertemente tanáticos, de un Tánatos asumido como la contraparte tenebrosa de Eros y de la lucidez (inclusive podría añadirse dos reelaboraciones agnósticas de asuntos bíblicos: la Resurrección de Cristo y el Juicio Final). El conjunto es desigual, pero ostenta logros apreciables en todas las líneas mencionadas, especialmente en la de cuentos psicológicos sobre la pasión (por ejemplo, "Infidelidad") y en la de cuentos de terror y locura. (671)

Al momento de respaldar la elección del cuento El beso de Elvira en el volumen en cuestión, R.G.V. estima lo siguiente:

Hemos elegido una muestra de esta última tendencia, porque ilustra de modo más pleno la paleta de Román: neurasténica, mórbida, sensual, decadente, agitada por un "alma inquieta", en la ruta del satanismo de Byron y Baudelaire, la narración extraordinaria de Poe, la desazón de los "poetas malditos", etc. (671)

En otro esfuerzo por presentar una visión panorámica de nuestras literaturas ${ }^{41}$, César Toro Montalvo desconoce a Román, pero indica

que al comenzar el modernismo en el Perú, habían ya grupos literarios constituidos. Uno ubicado a través del "Círculo Literario" que congrega al Partido Unión Nacional, cuya figura visible es González Prada, quien se encontraba residiendo en Europa. Otro, en la de "Enrique Alvarado", donde se reunían varios escritores e intelectuales, entre los cuales destacan Chocano, Carrillo; que mostraban su inclinación fervorosa hacia la literatura. Otro grupo conocido con el nombre de "Pablo de Olavide", reunía a Domingo Martínez Luján, José Fiansón, Clemente Palma, Enrique Castro Oyanguren y Federico Larrañaga. (33)

Como se puede notar, Toro Montalvo, al igual que Sánchez reconoce la existencia de grupos literarios establecidos de manera formal, los denominados "Enrique Alvarado" y "Pablo de Olavide". Y si bien agrega a estos dos frentes reconocibles el del "Círculo Literario", no coloca en ninguno de estos a nuestro autor. Parecería entonces que alguien como Román, cuyo norte estuvo marcado desde siempre por la disolución de su persona, no engrosó las filas de ningún grupo o tienda literaria. Pero lo que sí podría afirmarse es que los primeros esbozos modernistas fraguados en nuestro país nacerían efectivamente de tierras muy

${ }^{41}$ Historia de la literatura peruana. Tomo VII Modernismo. Lima: A.F.A., 1996. 
próximas a la de Román, y de la pluma del redactor de La Revista del Sur, tal como lo señala Francisco Mostajo ${ }^{42}$ :

Jorge Polar, mi ilustre paisano i maestro, fue el primero que, en el Perú dió a su cláusula galana el corte parisiense del modernismo. En Lima, la culta capital, aún no había surgido la pléyade "Enrique Alvarado" ó por lo menos principiaban recién a escarabajear cuartillas, cuando ya el escritor mistiano sublevaba á muchos con la fosforescencia i dislocaciones de su estilo, la tonalidad extraña de sus imágenes i el serpenteo eléctrico de su frase. Él antes que ninguno, desplegó, pues, en nuestra patria el estandarte de los cruzados del nuevo ideal. I no se crea que le proclamo iniciador por el espíritu de arequipeñismo, tan arraigado en mis paisanos. No. Lejos estoy de alentar insostenibles egoísmos de provincia. Hago historia i justicia i nada más. (38)

Otro crítico nacional, José Miguel Oviedo, en su espectroscópica visión de la literatura de Hispanoamérica ${ }^{43}$ tampoco cita a José Antonio Román en sus páginas, pero establece una consideración muy puntual sobre Clemente Palma que es necesario observar. Dice de él:

El gusto por el satanismo, el esoterismo y los tipos de psicología anormal, algo ingenuo a ratos, distingue al joven Palma y explica la notoriedad que sus relatos le ganaron en su tiempo: ese escalofrío de horror y esa sombría delectación criminal no habían aparecido antes en la literatura peruana... A Clemente Palma no le faltaba imaginación y hoy debemos reconocer que trató de introducir algo nuevo en la literatura peruana: la fantasía perversa y perturbadora. Lo que le faltaba era un estilo reconocible que hiciese menos forzada la extrañeza de su mundo. (107)

Sobre este último punto habría que señalar que buena parte de los gustos que Palma cultivó y llevó adelante distinguieron también a Román. Considero que el autor de Cuentos malévolos e Historietas malignas sí podría ser considerado el fundador de la literatura fantástica en el Perú por haber aportado el volumen inicial probablemente más sólido y homogéneo de la literatura de ese período, pero a la hora de establecer, por ejemplo, las consideraciones sobre la literatura de horror o de dominio siniestro, pienso que sí convendría estimar la obra de Román como un antecedente fundamental.

En el 2003, otra antología de cuentos trabajados por autores salidos de las aulas sanmarquinas ${ }^{44}$, recopilación hecha por Carlos Eduardo Zavaleta

\footnotetext{
${ }^{42}$ Francisco Mostajo. Antología de su Obra. Lima: Compañía Cervecera del Sur, 2002.

${ }^{43}$ Historia de la literatura hispanoamericana. Tomo 3. Postmodernismo, Vanguardia, Regionalismo. Madrid: Alianza Editorial, S.A., 2001.

${ }^{44}$ El cuento peruano en San Marcos. Lima: Fondo Editorial de la Universidad Nacional Mayor de San Marcos, 2003.
} 
y Sandro Chiri, vuelve a poner a José Antonio Román en la mira de los investigadores e interesados en la literatura. El cuento antologado en esta ocasión es El cuaderno azul. Los autores hacen referencia a nuestro autor en estos términos:

[J.A. Román es] una figura injustamente olvidada, y por ello es necesario reconocerla y divulgarla cada vez más. Graduarse de doctor en 1895 con una tesis sobre Enrique Ibsen es casi como estar al día con la literatura europea, como estaba el juvenil James Joyce, quien también amaba a Ibsen casi por el mismo tiempo. Luego, es autor de cuentos en que la psicología y el estilo se disputan la primacía. Por fin, es uno de los pocos doctorados tres veces en San Marcos, como la historiadora Ella Dunbar Temple. (362)

Y cierran la nota, apuntando:

Su destreza técnica y su morosidad para pintar retratos destacan en su única novela Fracaso (1918), que no fue tal, por supuesto. Tres años antes de que Pirandello estrenara, el 10 de agosto de 1921, Seis personajes en busca de autor, ya Román había entretejido su historia sobre los posibles enredos entre los autores y sus personajes. Él convierte en personaje a una dama real, a doña Lucrecia, de quien Lima la chismosa se hacía malas lenguas. Al publicar sobre ella, pierde a una amiga y a su pequeño círculo. La fantasía, pues, es un mundo difícil y aun peligroso. (362)

De todos los acercamientos a José Antonio Román, es indudable que Tauro del Pino y Ricardo Conzález Vigil nos proporcionan los detalles más reveladores de un autor poco conocido, sumido en una oscuridad difícil de desentrañar. No hay, en buena cuenta, mayores y/o mejores aproximaciones a un autor que pareció moverse entre dos polos opuestos: la búsqueda inicial del reconocimiento, a través de sus cuentos aparecidos en periódicos y sus libros publicados, y la autoexclusión o el olvido merced a su apartamiento de los círculos literarios habituales. Y, por si fuera poco, sus libros, difíciles de hallar, son gemas raras, entenebrecidas en los laberintos de las bibliotecas públicas y privadas.

José Antonio Román nace, efectivamente, en la ciudad de Iquique en 1874 , puerto conocido a lo largo de su historia como Tarapacá, Icaiza, Ique-Ique o Nuestra Señora de la Concepción de lque-que. Sobre el origen de su nombre, algunos investigadores afirman que éste proviene del aimara y que sugiere el acto de soñar o descansar, debido a la cantidad de lobos marinos $y$ aves en el lugar.

Datos históricos referidos a la zona dan cuenta de que alrededor de 1556 empieza la explotación de plata de Huantajaya, tiempo en el que el puerto 
de Iquique se constituye en el centro de desembarco de trabajadores y aventureros. El preciado mineral seguía ruta a Carangas, y de ahí a Arica, centro de las Cajas Reales. Sin embargo, hacia la mitad del siglo XVIII la escasa población existente en el puerto continuaba viviendo fundamentalmente de la pesca. Además, la sequedad del entorno y la ausencia de agua desestimaban al puerto como un lugar de residencia.

A inicios del siglo XVII la futura cuna de nuestro autor fue saqueada por una flota pirata. A fines de ese mismo siglo, tras la revolución de Túpac Amaru, la población extranjera del interior se trasladó allí mientras aguardaba la llegada de un barco que los condujese fuera de la zona. Además, tanto en 1808 como en 1815 se producirían sucesivamente dos insurrecciones.

Tarapacá fue asolada repetidas veces durante la época de la Colonia. Ya para inicios del siglo XIX existían dos barrios representativos en el puerto: La Puntilla, para los extranjeros; y El Morro, para los indígenas y mestizos. Con don José de San Martín como Protector del Perú, la situación en el sur no varió demasiado. Iquique fue sitiada con el propósito de cortar el aprovisionamiento, además de perseguir el contrabando y contener la fuga realista, situación que se mantuvo hasta fines de 1822.

La aduana del puerto quedó restaurada recién en 1830, hecho que posibilitó la exportación de más de ochocientas toneladas de nitrato. Pero si bien la situación económica parecía ir en auge, la vida social daba la impresión de radicalizarse a raíz del respaldo de las autoridades a cierto espíritu xenófobo: se acusaba a los extranjeros afincados en la zona de ejercer el monopolio de determinados productos. Pero era evidente que la decadencia de lquique era más bien el producto de situaciones derivadas de la inestabilidad política y no de los monopolios económicos ejercidos por los extranjeros.

En 1843, fecha en que don Ramón Castilla, futuro gran benefactor de Iquique e hijo ilustre de Tarapacá, desconoce la autoridad de Manuel Ignacio Vivanco como Jefe Supremo de la Nación, el puerto es elevado a Puerto Mayor, gracias a lo cual se pudo importar y exportar productos de manera directa, sin necesidad de ser gravados en Arica o en algún otro puerto. Las embarcaciones peruanas podían internar víveres de cualquier clase y pagar la mitad de los derechos correspondientes; los extranjeros, en cambio, estaban afectos al pago.

Si bien hacia 1870 los prejuicios contra los chilenos habían aumentado considerablemente, venía a ser muy importante para el desarrollo de la ciudad la presencia de extranjeros, cuyo principal núcleo de sociabilidad estaba constituido por las compañías de bomberos, las mismas que se encargarían de preservar el orden al abandonarse la ciudad durante la ocupación chilena. 
Epidemias de tifus en el puerto y casos de fiebre amarilla en las ciudades aledañas se presentarían tanto a finales de 1860 como a inicios de 1870 . Un incendio destruyó hacia 1875 buena parte de la ciudad. Además, en 1877 un terrible terremoto hizo estragos, luego de lo cual el mar ingresó trescientos metros costa adentro.

Pese a haber estado sumida momentáneamente en la oscuridad durante 1873 , debido a la suspensión del alumbrado a gas, no haber gozado del servicio de alcantarillado, sus calles haber carecido de la pavimentación requerida, no haber existido una política de control de ingreso de inmigrantes, ni un cuerpo de policía organizado, la aldea conoció una expansión admirable. Gracias a las exportaciones de salitre, Iquique no desapareció; es más, otras localidades del litoral sur-peruano corrieron igual suerte debido a la importante industria salitrera.

Por otro lado, la prensa local alcanzó por esas fechas un desarrollo más o menos significativo; circularon, con vidas irregulares y disímiles, El Mercurio de Tarapacá, El Comercio, El Heraldo Americano, La Voz del Pueblo, La Estrella y El Tiempo, periódicos en los que muchos de los escritores de la época colaborarían con artículos, cuentos y reseñas.

Fue en este escenario donde nuestro autor nació y vivió sus primeros años, hasta 1888, fecha en la que se trasladó a Lima embargado de propósitos muy puntuales y con una idea claramente definida de lo que la literatura debía merecer de un observador acucioso; así lo evidencia este fragmento inicial de su trabajo Enrique Ibsen y su teatro, leído y sostenido por su autor al optar el grado de doctor en la Facultad de Filosofía y Letras de la Universidad Mayor de San Marcos:

En estos tiempos de laudable cosmopolitismo literario en que ya las escuelas han abjurado un tanto de sus restrictivas tendencias fanáticas, sacrificando algunas de sus doctrinas en pró de la comunidad universal, ninguna de las actuales literaturas puede sustraerse al escalpelo de una crítica seria é ilustrada.

Ya instalado en Lima, Un cuento para Lesbia y Flor de loto, pequeños esbozos narrativos de nuestro autor y transcritos al inicio del presente trabajo, constituyen textos fundamentales de Román, no solo porque poseen toda la impronta modernista de la época y constituyen sus esfuerzos narrativos más aurorales hallados hasta la fecha, sino porque aparecen en El Iris, la efímera y reducida publicación peruana, de la que, en sus cinco números, ofició de director un jovencísimo Clemente Palma, y en la que este mismo autor dio a la luz La decadencia en América ${ }^{45}$.

${ }^{45} \mathrm{~N}^{\circ} 2$ de El Iris, 1896. 
Boyd G. Carter, quien realizó una investigación sobre esta revista ${ }^{46}$, sostuvo que ella constituye

el primer órgano del modernismo en el Perú. (293)

En ella colaboraron voces importantes como Salvador Rueda, Abraham López Penha, José M. de Heredia y Nicanor Bolet Peraza, o los nacionales Federico Larrañaga, Mercedes Cabello de Carbonera, Sixto Morales o el mismo Clemente Palma, lo que demostraría, a su juicio, que los emergentes escritores peruanos

estaban notablemente enterados de la expresión cultural de Francia. (291)

La mencionada publicación, además, resulta reveladora en lo que se refiere a las pulsiones que el decadentismo desencadenaba o inoculaba por ese entonces en nuestros jóvenes literatos. En el primer número de El Iris, su director publica la carta que Mercedes Cabello de Carbonera le dirigiera a él y en la que la autora rechaza el decadentismo francés y a sus prosélitos peruanos. En su respuesta, La decadencia en América, un Palma no muy firme, con afanes tal vez algo disminuidos por tratarse de una escritora de renombre con la que probablemente no deseaba verse enfrentado en un debate, duda en su adhesión o rechazo al decadentismo. A decir del mismo Carter, el comentario de Palma sería uno

de doble vía [puesto que da cuenta de una] admiración por la estética decadentista, y sin embargo vacila en adherirse como adepto entusiasta. (285)

José Antonio Román también se adscribiría a este temperamento imperante, pero con las dudas y los temores que su juventud, al igual que Palma, le dictaban. Ambos son probablemente dos de los dos escritores que más al tanto estaban de las corrientes extranjeras llegadas a estas tierras. Ambos fueron testigos y sujetos de primer orden de ese cambio de sensibilidad que venía creciendo en tierras americanas.

Como se sabe, con la entronización del Modernismo -movimiento estético americano, aparecido como una guía de los espíritus, además de una inclinación intelectual y cultural- va a aparecer lo nuevo como una norma de la creación artística y la ruptura de los convencionalismos. Época, más que escuela, el Modernismo, a decir de Bella Jozef, en su estudio sobre los vasos comunicantes entre éste y la modernidad ${ }^{47}$.

46 "Darío y el Modernismo en El Iris (1894) de Clemente Palma", Revista Iberoamericana, Vol. 33. № 64, pp. 281-292.

47 "Modernismo y vanguardia (Del Modernismo a la Modernidad)" en: Nuevos asedios al Modernismo, Madrid: Taurus Ediciones, 1987. 
significó, para América Hispánica, el acceso a la independencia literaria, dando expresión singular a los temas universales, como manifestación de una nueva sensibilidad y busca de la expresión adecuada a esa nueva sensibilidad. Verdadero rito de paso, el Modernismo marcó la madurez literaria de un continente, a través de la capacidad de contribución original. Delante de lo temporal, se observa la decisión de enfrentar la modernidad y fundirse con ella. (65)

Y no fue, desde luego, una expresión literaria - primero prosista, más tarde poética - de evasión de la realidad, como ya ha sido largamente demostrado.

El llamado venero exótico de los modernistas [dice Ivan A. Schulman en su estudio sobre el particular ${ }^{48}$ representaba una manera de concretizar anhelos estéticos e ideales vedados por la realidad cotidiana. El positivismo, por un lado, y la incipiente modernización socioeconómica, por otro, crearon actitudes cuentistas, y un ambiente materialista que los modernistas, frustrados y alienados, no lograron aceptar. Frente a esta realidad construyeron otro, un mundo ideal, una visión soñada, los cuales terminaron siendo para muchos de ellos, la única realidad valedera. (34)

Muchos de los acercamientos al Modernismo apuntan en esa línea. Gutiérrez Girardot, por ejemplo, sostiene que éste se destacó por una clara postura de carácter ideológico, y que contestaba a la secularización del pensamiento propio del XIX con ciertos reemplazos de la religión, llámense ocultismo, neomisticismo o deificación artística. $Y$ es que el escritor modernista era un intelectual confrontacional, pero investido de ciertas consideraciones todavía activas del pasado, entregadas a una suerte de aquiescencia o adaptación, de tal suerte que no constituyeran una confrontación demasiado rígida con la denominada cultura dominante.

Pero no solo en La decadencia en América, había hecho Palma una defensa cerrada del espíritu decadente. En Filosofía y Arte, de 1897, tesis presentada para optar el grado de doctor en la Facultad de Letras ${ }^{49}$, el autor peruano señala:

¿En dónde está la verdad religiosa, el verdadero concepto filosófico de la vida, la legítima belleza poética? En todas partes, señores, colocadas en el centro mismo de la vida psíquica parten de ellas radios en todas las direcciones. Sí, señores, la belleza y la verdad son centros a los que se llega por todos los caminos, tanto por la vía recta

48 "Modernismo/Modernidad: Metamorfosis de un concepto", en: Nuevos asedios al Modernismo. Madrid: Taurus Ediciones, 1987.

${ }^{49}$ Lima, s/n, 1897. 
que sigue un espíritu sano, como por la ruta torcida por la que se encaminan las almas enfermas y las razas degeneradas. (33).

Bien hace notar Gabriela Mora, en un volumen dedicado al autor de Historietas malignas ${ }^{50}$.

cuán cerca están estas palabras de los postulados estéticos de modernistas y decadentistas en cuanto a la libertad necesaria para la creación, y la posibilidad de extraer belleza aun de lo horrible y feo. (41)

Román lo hizo así. Sacó provecho de la posibilidad de obtener resultados estéticamente bellos y sugerentes, explorando en la negrura, el abismo y la desesperanza.

La novedad que ansían los modernistas [dice Francisco Mostajo ${ }^{51}$, al respecto de estas búsquedas en y desde nuestras tierras] favorece también la formación de la literatura americana. Los artistas de hoy, hastiados de lo vulgar i anhelantes de sensaciones desconocidas, se fascinan de todo lo que tiene la inmaculez de lo original i lo nuevo i el incentivo de lo no desflorado. Los escritores franceses, víctimas de esta fiebre de lo extraño, recurren, para hallar motivos geniales de inspiración, á excitantes poderosos, como el ajenjo, el haschich ó el éter, i se entregan á todas las extravagancias enfermizas i monstruosidades delirantes. En busca de lo exótico, unos peregrinan á la India, como los budistas, ó al país oriental, como los japonistas, i otros se remontan á las edades antiguas, como los parnasianos ó á los tiempos caballerescos como los medioevales. I no pocos asisten á la misa negra del sábado: se sumergen en las tenebrosidades de la cábala, como los macábricos ó los diabólicos...

No sabemos, empero, si fue el mismo Román quien se declaró líder de la escuela decadente en el Perú o si fueron sus propios escritos los que le otorgaron ese calificativo. Si nos guiamos por el comentario aparecido en Neblina -no confundir esta publicación, cuyos redactores fueron Federico Blume y Joaquín Suárez La-Croix, con La Neblina, cuyo director, editor y propietario fue José Santos Chocano- en el que se fustiga a Román, tendríamos que pensar que sí. Pero es claro que si Román se erigió en el jefe de la escuela decadente peruana, no fue precisamente por los múltiples cuentos y viñetas aparecidos en los periódicos de la época, sino por la consolidación estilística y formal que representa, por ejemplo, Hojas

\footnotetext{
${ }^{50}$ Mora, Gabriela. Clemente Palma en su versión decadente y gótica. Instituto de Estudios Peruanos (IEP), 2000.

${ }^{51}$ Francisco Mostajo. Antología de su Obra. Lima: Compañía Cervecera del Sur del Perú, 2002.
} 
de mi álbum. Transcribo la crítica mencionada, aparecida en una columna titulada "Cero y van dos"52, con el ánimo de mostrar cómo eran recibidos por una parte de la opinión pública y la crítica los empeños narrativos de Román. Nótese que el texto lleva la firma de Fernando Fierro Fernández, como bien señala Tauro del Pino en 1950; no es, entonces, como apunta Escobar en 1960, que Román empleara tal seudónimo.

Existe por ahí un literato que asegura ser el jefe de la escuela decadente en Lima, y el cual alardea de no obedecer a ninguna regla literaria. Y no miente.

Este señor, tan propenso a los antojos, está siempre interesantísmo. El día que amanece de humor se le antoja escribir sobre Babilonia, y en efecto lo hace, tan solo por el gusto de satisfacer su deseo.

Mas no es esto lo gracioso, sino que nuestro hombre escribe continuamente sobre lo que no conoce, falseando la verdad histórica; y para remate de fiestas en un estilo tan campanudo que sus artículos no pueden ser digeridos, ni con aceite.

Algo más; este señor don Antonio se jacta de haber introducido en el castellano palabras nuevas como amatistar y otras. ¡Vaya que tiene mérito!

Para muestra de las composiciones del señor Román, insertaremos partes de algunas de ellas.

Describiendo una iglesia dice:

"En lo alto de las bóvedas, cuyos esfumados contornos temblaban al través de luminosa bruma, y como fantásticos seres alados columpiaban su ensoñadora claridad las girándulas de cristal con abdómenes metálicos, y su luz espejeante en las telas, pastosa en las ropas masculinas, chilladora y riente en los brazaletes y diademas, iba parpadeante, soñolienta, a reclinar su radiosa cabeza sobre los empolvados arabescos de las hornacinas y apolillados zócalos de las esculturas, allá, en los ángulos penumbrosos del templo".

¿Han entendido, mis amables lectores?

¡Ni la espada de Alejandro podría desatar este nudo!

Sin embargo analicemos:

"En lo alto de las bóvedas, cuyos esfumados contornos temblaban". Conténganse. ¿Los perfiles temblaban?, ¿y al través de luminosa bruma?

${ }^{52}$ En: Neblina, edición correspondiente al 12 de enero de 1895. 
Señor Román, ni los perfiles o contornos de una bóveda tiemblan, y mucho menos al través de luminosa bruma.

"Y como fantásticos seres alados columpiaban su ensoñadora claridad las girándulas de cristal con abdómenes metálicos"... ¿Qué? Girándula, dice la Academia, es rueda llena de cohetes que, dando vueltas a la redonda, los va despidiendo, ¿y cree usted don José que en la iglesia haya cohetes y en una rueda de cristal (según $U$. dice) con abdómenes? Abdomen es la cavidad que contiene la mayor parte de los órganos digestivos, etc., etc. En cuanto a lo de abdómenes metálicos, el demonio que lo entienda.

Y dice usted que las girándulas columpiaban (en todo caso daban vueltas) su ensoñadora claridad. ¡Psh!, cuánto desatino. ¡Jesús! ¡Jesús!, "y como fantásticos seres alados". No sea usted necio, hombre.

Continuemos:

Y su luz espejeante en las telas" (¿Esto en qué idioma está escrito?) "Espejeante" no es castellano, y "pastosa en las ropas masculinas" (dos disparates unidos).

¡Bah!, pues en la primera ocasión que tenga le regalo al señor Román "ropas femeninas". ¿Me las acepta?

Concluyamos:

"Chilladora y riente en los brazaletes y diademas" (¿quién chilla y ríe? - ¡la luz!), "iba parpadeante, a reclinar su radiosa cabeza sobre los empolvados arabescos de las hornacinas y apolillados zócalos de las esculturas, allá en los ángulos penumbrosos del templo".

¡Basta!, ¡basta! Jamás se ha dicho mayor número de dislates.

Declaro que el señor de los antojos está loco.

¡Ducha y más ducha! Y si protesta, ¡camiseta de fuerza!

Con razón se llama usted jefe de la escuela "decadente", no miente usted; porque a la verdad es usted la personificación más grande de decadencia literaria.

Mi propósito fue trascribir varios párrafos de don Antonio.

Mas si con un parrafito

Tengo tanto que decir

¿A qué diablo trascribir

Un artículo enterito? 
Ese decadente empeño

Y aquel arte japonés,

¿No ves, Antonio, no ves

Que carga, aburre y da sueño?

Deja al fin la decadencia

Y no escribas... candideces;

Pues hace ya muchos meses

Que nos... mueles la presencia. (11)

Una pieza emblemática de ese espíritu decadente constituye, sin duda, El beso de Elvira. Sin embargo, hay en Román, como autor, un tránsito que se produce desde sus textos propiamente modernistas, iniciales, hasta su cumbre primera, que viene a ser Hojas de mi álbum, distanciados en la forma y en el fondo de esos intentos aurorales. El libro de cuentos en mención aparece en Madrid en 1903, vale decir, un año antes de la publicación de Cuentos malévolos de Clemente Palma. El volumen, integrado por veinte textos - La walkirya; En el Nilo; La piedad divina; el ya nombrado El beso de Elvira; Ensueño de absintio; El tonel de whisky; La última ondina; Los hipocampos; La esposa del sr. De Chantel; La reina de Saba; La pur sang; Persépolis; Alabastrina; La señora Marionnette; Infidelidad; En el huerto de Arimatea; El quinto Gemara; Una profesa; Atavismo y La linterna japonesa-, trae prólogo de su autor, titulado Unas pocas palabras y firmado en lquitos, el 18 de mayo de 1902, que dice así:

Estos cuentos que doy ahora a la estampa son hojas arrancadas literalmente de mi álbum. Escogidos al azar van tales como salieron de los puntos de mi pluma. Muchos de ellos son cuadros extraídos de la vida real, especie de instantáneas que aún guardan los trazos de una fidelidad desesperante. He querido que permanezcan así por tener para mis fines ulteriores la importancia de documentos humanos, que reaparecerán más tarde transformados en novelas. Más de uno de estos episodios ha sido vivido por mí, y de alguno que otro he sido mudo espectador. No temo arrojarlos a los vientos de la publicidad, ni me aflige la suerte que corran porque como padre siempre los guardo cariñoso para defenderlos o protegerlos.

Precisamente El beso de Elvira ${ }^{53}$ es quizá el ejemplo más paradigmático de la obra cuentística de Román. No sólo constituye uno de los

\footnotetext{
${ }^{53}$ Apareció inicialmente en La Gran Revista, segunda época de La Neblina, edición n॰ 8 del año I, correspondiente al 16 de septiembre de 1897; luego en Hojas de mi álbum.
} 
principales relatos del género de horror hecho en el Perú, sino que en él se funde lo que, a juicio de Gabriela Nouzeilles ${ }^{54}$, constituye el propósito deformador en la narrativa modernista al momento de acatar las premisas científicas de su tiempo. Por eso es que se presentan cuentos en los que se entroniza la enfermedad pese a que la sociedad la temía o intentaba someter. El elemento corporal se erige así en el territorio donde se entabla una contienda de corrientes ideológicas. Dicha instrumentalización del cuerpo humano se hermana con una especie de inoculación de significados que la recategorizan como un ámbito comunicativo. Considérese además que la transición entre milenios se corresponde con una lectura apocalíptica, en la que el éxito del capitalismo exonera a la persona de su concepción de entidad psicosomática integrada, y en la que el maltrato y/o la tortura devienen en relaciones de poder. Transcribo el referido relato:

\section{El beso de Elvira}

Hacía una hermosa noche de luna en aquella elegante terraza guarnecida de torneados balaustres de pórfido y esculpidas jardineras de mármol que ostentaban exóticas flores de embriagador perfume. Por entre la columnata percibíase parte del jardín, y las magnolias, al agitarse movidas por la brisa, nos enviaban cariñosamente sus deshojados pétalos un tanto descoloridos. En lontananza sereno, difundiendo sugestiva paz, el cielo se extendía palpitante de luz.

Allí nos encontrábamos reunidos en franca charla alrededor de una frágil mesita, Elvira, nuestra espiritual anfitriona, el pintor Corot y yo, tomando té.

Una dulce sensación de bienestar inundaba nuestras almas, sellando los labios y haciendo que nuestras pupilas se clavasen extasiadas en lejanos paisajes envueltos en una tenue bruma de plata, que les daba cierto tinte de ensueño. De las tazas de té ascendían blancas nubecillas de humo que semivelaban las correctas y delicadas facciones de Elvira, la cual, pensativa, reclinaba su hermosa cabeza sobre el respaldo del sofá.

De repente, deslumbrándonos con su triunfadora mirada, alzando en alto su taza, la apuró de un sorbo, y al colocarla en el platillo, exclamó:

"Premio con el más exquisito de mis besos al que conmueva hondamente mis nervios imaginando la más abracadabrante fantasía". Y al concluir estalló en una ruidosa carcajada que hizo estremecerse en su dorada jaula al mirlo que, soñoliento, se columpiaba sobre nuestras cabezas.

54 "Narrar el cuerpo propio. Retórica modernista de la enfermedad". En: Estudios. Revista de Investigaciones Literarias, № 9, 1997, pp. 149-176. 
Entonces Corot, mirándola intencionadamente, contestó: Elvira, mío va a ser ese beso; porque le aseguro a usted que mi narración es muy terrorífica. ¿Sonríe usted? Pues bien, hela aquí:

Tendría yo en aquella época veintiséis años a lo sumo y acababa de llegar de Italia, Ileno de ardientes ideales y ganoso de gloria. Mis primeros cuadros merecieron la atención del público. Un crítico dijo que mi manera era violenta, que mis figuras tenían contorsiones de histéricos y que en la combinación de los colores había algo de pesadilla; en una palabra, me calificaba de artista desequilibrado, casi vesánico.

Cuando concluí de leer el periódico, lo rasgué furioso y, con la cabeza entre las manos, junto a la lámpara a media luz y de bruces sobre mi modesta mesa de trabajo, permanecí largas horas sumergido en penosa meditación. Y pensé con amargura en el derrumbe de mis ensueños, en la inutilidad de mis esfuerzos para renovar el colorido en la pintura y maldije despechado la estupidez del público, cuyos gustos chocan siempre con los ideales del artista.

Aquel insomnio se prolongó mucho. Una torre vecina dio horas. Las campanadas me sacaron de mi atonía, y vacilante como un ebrio, casi automáticamente, abrí la puerta y me lancé a la calle.

Un viento frío mezclado de llovizna azotó mi rostro y me hizo tiritar. Un coche retrasado rodando violentamente sobre el macadám me arrojó al paso una ráfaga de claridad; después torció por una bocacalle, y ese movimiento brusco me permitió ver en el fondo del carruaje, indecisa, la pálida silueta de una mujer que parecía temblar envuelta entre sus pieles. Luego un vago ruido que se alejaba, los faroles de luces dudosas y las aceras interminables, extendiéndose en dos láminas pálidas y brillantes de agua, mientras a mi alrededor volvía a reinar un silencio pavoroso.

Tuve una extraña sensación de miedo, una vez vuelto en mí, al hallarme vagando a deshoras por las calles de la ciudad en aquella lluviosa noche de invierno. ¡Qué soledad tan absoluta! Ningún otro rumor que el de mis pasos despertando los dormidos ecos; ningún rayo de luz que se filtrara a través de las entornadas maderas de los balcones. Una tranquilidad de cementerio flotaba en el aire, y llegué a imaginarme que una repentina peste había hecho desaparecer a los habitantes de aquella villa, salvándome yo solo de sus estragos.

Varias veces quise volver a mi casa, pero un secreto impulso espoleaba mi voluntad, y sin ser dueño de mi albedrío avanzaba errante, febril, las crispadas manos hundidas en los bolsillos del abrigo. El cansancio me rindió y me hizo caer sobre un guardacantón, resuelto a no dar un paso más. 
El alba me sorprendió allí sentado. Por el oriente se difundía un suave color de rosa con matices de oro viejo; Venus lucía radiante, como si celebrara la próxima salida triunfal del sol. ¡Qué agradable es el amanecer! ¡Cómo huyen a la desbandada las nieblas que traban durante la noche, red de ensueño en torno de los objetos! ¡Con qué placer el alma angustiada por terrores nocturnos mira asomar el sol!

También fue un alivio para mi congoja, pues disipó completamente mis aprensiones y me dio nuevas fuerzas para la lucha. Me arrepentí del instante de cobardía en que estuve a punto de claudicar. ¡Vano empeño el de los retardatarios! La jornada de la gloria es sangrienta en verdad, pero los espíritus bien retemplados la emprenden animosos, impávidos, siempre anhelantes del triunfo. Yo me dije que lo haría como tantos otros, a despecho de todo, y entonces prendió en mi cerebro la idea del cuadro que me ha hecho célebre, mi obra maestra como dicen por ahí; me refiero a "La exaltación de la bienaventurada Lidwina".

Aquí empieza mi cuento. Días enteros, allá en la soledad de mi taller, devoré ansioso, presa de una sobreexcitación nerviosa, muchos antiguos centones de vidas de santos y mártires buscando a aquel que debía encarnar mi ideal. Al fin lo encontré en Lidwina, nacida en el siglo XIV en Schida de Holanda. De una belleza incomparable, pero rebosante de piedad, obtuvo del Señor que hiciera caer sobre sus frescas carnes de virgen las más repugnantes enfermedades. Desde ese instante, condenada a un forzado reposo sobre su miserable camastro, pasó treinta y cinco años en medio de los más crueles dolores, todo su adorable y blanco cuerpo cubierto de purulentas úlceras.

No satisfecha aún su inextinguible sed de sacrificio, suplicó al Eterno, en cierta ocasión en que la peste desolaba a Holanda, que fuera ella su primera víctima. Dios escuchó sus votos, y dos pústulas brotaron en su pecho; pero la mártir pidió una tercera, y esta última más horrorosa la comió la nariz y le hizo saltar uno de los ojos, mientras el otro se cerraba para siempre a la luz del día.

Siempre llena de fervor, arrasada en ardientes lágrimas, impenetraba el favor divino. Alma tan pura como ésa, debía tener sitio preferente en el Cielo. Cristo la llamó a sí y, entre nubes de gloria y de perfumes sacros, escoltado por un enjambre de querubines, vino una noche por ella. La ciudad se conmovió grandemente con tan maravilloso suceso, y desde entonces fue ella la patrona de los enfermos.

Pues bien, yo quería trasladarla al lienzo, toda palpitante de vida, pero cubierta de llagas, en el instante mismo en que tendiendo las manos al Señor subía al Cielo aclamada por los coros de ángeles.

Este era mi pensamiento: Una noche destemplada, lluviosa, bajo un cielo horriblemente gris; una miserable cueva, muy fría, apenas guarnecida la angosta 
puerta por toscas cortinas, y adentro, pedida en misteriosa penumbra, acariciada por los pálidos reflejos de una lamparilla, exangüe, las flacas manos cruzadas sobre el seno, los descoloridos labios resecos por la fiebre, las pústulas del rostro destilando virus, tendida sobre su lecho la desventurada Lidwina. Así realizaba el objetivo de mi existencia, así colmaba las aspiraciones de mi espíritu, que era pintar el cuerpo humano, no vigoroso, ágil y pletórico de salud, sino la carne enferma, gangrenada por los vicios, corroída fibra a fibra; el cuerpo con todas sus hediondas lacerías, porque yo detestaba cordialmente los miembros sanos, rebosantes de savia vital, de igual manera que los temperamentos equilibrados de los burgueses.

Pero tuve desde el comienzo de mi obra una dificultad casi insuperable; me faltaba un soplo de fe religiosa, de ese entusiasmo ingenuo de los hagiógrafos al narrar los milagros de los santos. Y recorrí los templos permaneciendo horas enteras envuelto en su dulce penumbra cuando cae la tarde y en los retablos las vírgenes, semi-difusas, adquieren en sus rostros ese vago colorido de cirio pascual y sus cabellos parecen embeberse en la ascendente oscuridad mientras, en sus vidriosas pupilas algún postrer rayo de sol, filtrándose al través de una alta ojiva, viene a morir con trémulas escintilaciones. Yo procuraba ganar en mi cerebro esas caras ovaladas, de rasgos finísimos, casi espiritualizados, que instintivamente hacían pensar en el martirio; esas manos diáfanas, de dedos largos como pistilos de flores, incoloras, siempre cruzadas sobre el seno; y esos cuerpos magros, nerviosos, casi sin sexo que cubrían las túnicas castas y ondulantes. Lidwina tenía que ser, como esas vírgenes, de una belleza litúrgica, algo así como una figura de los cuadros del Primitivo.

¿Y dónde encontrar un modelo que satisficiera todas esas condiciones? Las muchachas que venían a los talleres de los artistas eran por lo común bien formadas, ricas en carnes y colores; demasiado libres en sus maneras. Era inútil buscarlo entre ellas.

Pero la suerte vino en mi auxilio. Una noche en que obsesionado por mi cuadro vagaba a deshoras por la ciudad, casi al entrar en mi casa, un brazo descarnado y tembloroso, surgiendo de la oscuridad de una puerta, me detuvo y al mismo tiempo una voz femenina, casi enfermiza, imploró mi caridad. Nerviosamente la cogí por el puño y arrastrándola conmigo la llevé al cercano farol. Entonces pude verle el rostro; era una mujer, muy joven todavía, una de esas criaturas descarriadas que principiando por la mendicidad pronto terminan en la prostitución. Le pregunté cómo se llamaba y me dijo que Ana. Luego, animada por mi cariñoso acento, me contó en breves palabras su existencia de hija del arroyo. Entre tanto al contemplarla tan desmedrada, de una intensa palidez y con sus profundos ojos azules de mirada ruborosa, casi mística, una idea me asaltó de súbito: bien podía esa niña servirme de modelo. Y sin reflexionar, bruscamente, le dije: "Oye, chiquilla, ¿quieres venirte conmigo?" 
La cogió de sorpresa mi pregunta, miróme un instante con recelo, y titubeante, como avergonzada de su acción, muy bajito, con voz casi imperceptible, murmuró que sí. Me había comprendido mal la pobrecilla.

Una vez en mi habitación le expliqué con claridad el móvil de mi conducta. Cuando concluí pareció satisfecha y hasta creo que intentó sonreírse.

Al día siguiente, muy de mañana, poseído por la fiebre de la inspiración, comencé a trabajar. La cosa marchaba a las mil maravillas, y al dejar los pinceles, terminada la tarea, pude lanzar una exclamación de alegría. El conjunto era seductor. La santa aparecía adorable en su actitud yacente, semidesnuda, mostrando su casto vientre de un rosa pálido, aplanado, y cuya curva ideal ascendía a perderse en el tórax muy saliente, dejando percibir, acusadas distintamente bajo la descolorida piel, las costillas, como si los estertores de la muerte quisieran hacerle estallar el pecho; el seno izquierdo estaba roído por una horrible pústula que se extendía hasta el nacimiento del cuello. Un pie descarnado, con extraño color de marfil, se asomaba por debajo de los cobertores. No podía quejarme. Pero donde volvió a presentarse la dificultad de mi obra fue en el rostro de Lidwina.

¿Cómo pintar con exactitud impresionadora un rostro así? Luego Ana tenía una faz hechicera de las que se desprendían efluvios de bondad y ternura. Yo no podía avanzar más. Sus ojos sugestivos, de mirada cálida, apasionada, semi velados por sus larguísimas pestañas de oro, me retenían en el asiento, inmóvil, completamente fascinado. $Y$ era que poco a poco su aire de ingenuidad y su dulce pasivismo a todos mis caprichos de artista, violentada por el ardor de la composición, habían cultivado mi voluntad y concluido por apoderarse de mi ánimo.

Estaba perdido; mientras me enamorara esa mujer no podía continuar mi cuadro.

Y rabioso contra ella, contra mí mismo, pasé noches enteras presa de dolorosos insomnios. ¿Qué hacer?, me preguntaba en medio de mis nocturnas angustias.

¿Quién sopló en mis oídos esa idea satánica? Tal vez fue un espíritu malévolo, quizás el diablo que a trueque de mi gloria quería la posesión de mi alma. El caso es que resolví maquiavélicamente envenenar su sangre y destruir la belleza de su rostro. De ese modo me libertaba de su amorosa esclavitud y concluía mi obra, pues vencía el único obstáculo para su realización.

Urdí un plan siniestro, y una vez, con engaño, aprovechando su inexperiencia, le inoculé en un brazo el virus de la más desastrosa de las enfermedades venéreas. Ella reía cándidamente creyendo, en su ignorancia, que era un paliativo para aplacar la neurosis que tanto trabajaba su débil organismo. ¡Infeliz! ¡La había condenado a la muerte!

Cuando el mal hizo sus estragos estampando en la tersura de su piel sus repugnantes huellas; cuando, como a Lidwina, floreció en asquerosas pústulas en el rostro y en el seno, entonces yo, con salvaje alegría, borracho de entusiasmo, 
cogí los pinceles y sordo a sus gemidos, con esa brutal crueldad del poseso, en pocas sesiones trasladé a la tela con espeluznante fidelidad esas lacras que eran como el florecimiento del pecado en esa carne de cirio bendito, casi santa, de la bienaventurada Lidwina.

Pocos días después murió Ana torturada por horribles dolores. Un atroz remordimiento se apoderó de mí, y cada instante, durante mis sueños, creía verla con su aspecto tranquilo, con su dulce mirada de víctima que ignora por qué se la sacrifica, reprochándome mi infame acción. Mis noches fueron pobladas de vengadores fantasmas, de horrendas visiones, que iban lentamente obsesionando mi cerebro, y en cierta ocasión -créanme ustedes que no fue locura- sentí sobre mi frente el leve roce de unos labios delgados, fríos como una piedra. Eran sin duda los suyos que me besaban como solía ella hacerlo durante su vida todas las mañanas.

Yo me creí perdonado, y llorando de placer, de rodillas en mi lecho, me esforcé por recordar las oraciones infantiles, pero fue inútil, y sólo pude exclamar: ¡Ana, mi bondadosa Ana, yo fui muy cruel para contigo, tanto como tú eres buena para con este criminal!"

A pesar de todo no recobré completamente la quietud de mi espíritu. Algo así como una maldición pesa sobre mí; no he vuelto a emprender ninguna otra obra maestra y hace tiempo que un sordo disgusto por la existencia y el arte me va dominando. Desde entonces quedé enfermo, cansado y triste. Algunas canas platearon mi cabellera y profundas arrugas ajaron mi rostro. Nunca más volví a pintar. Sólo espero que venga ya la muerte a libertarme de estos atroces remordimientos.

Luego, bajando la voz, con la mirada pensativa, concluyó: "ya ve usted, Elvira, con cuánta sobrada razón podía asegurarle a usted que el premio será mío". De pronto se estremeció como a impulsos de un calofrío, miró con sobresalto en torno suyo y cogiendo su taza de té la apuró rápidamente de un solo sorbo.

Cuando calló el narrador, todos permanecimos en silencio durante unos minutos, como si una súbita meditación hubiera embargado nuestras mentes. Después, Elvira continuó impasible, siempre risueña, la vista clavada en el fondo del jardín fantásticamente iluminado por la luna, que descendía pausada y magnífica. Yo la contemplé asombrado, preguntándome lleno de horror si esa mujer no tenía nervios; porque esa historia ya fuese horrible verdad o fruto de una delirante imaginación, era sombríamente cruel. Corot, de bruces sobre la mesa, ajeno a lo que pasaba a su alrededor, seguía meditabundo, como abrumado por penosos recuerdos.

Una rabia sorda, incontenible, germinó en mi pecho contra esa mujer de formas finas y sensuales, de actitudes estudiadas para enardecer a sus adoradores. 
Asimismo pensé con amargura que hubo un tiempo en que la amé con pasión, y al encontrarla ahora convertida en cortesana, rodeada de lujo y de amantes, ostentando desdeñosa su fría sonrisa de escéptica, brotó en mí repentinamente la idea de matarla.

En seguida con tono chancero grité: "Llegó mi turno, hermosa Elvira". Y bruscamente, atropellando las palabras, aguijoneado por un incomprensible deseo, narré lo siguiente:

"Soy de temperamento nervioso, demasiado aprensivo, y al acostarme, cuando me rodean completamente las tinieblas, un extraño temor me sobrecoge, y largo rato, bien cerrados los párpados, permanezco inmóvil en mi lecho en espera de algo desconocido, creyendo escuchar rumor de pasos y batir de gigantescas alas. Muchas veces he pensado en seres sobrenaturales que viniesen a danzar en mitad de mi estancia.

Una vez, a eso de las dos de la madrugada, percibí un ligero ruido sobre mi cabeza, y al alzar la vista contemplé horrorizado a un enorme vampiro posado fuertemente en la cabecera de mi lecho, fijas en mí con insólita tenacidad sus redondas pupilas relumbrantes como dos encendidos carbones. Me agité convulso, quise gritar, pero sólo se escapó de mi garganta un gemido ronco, casi inarticulado.

El monstruo se movía pesadamente, y hubo instante en que entreabriendo su chato hocico pareció querer hablarme. Un sudor de muerte bañó mis sienes, y en medio de mis congojas pensé para mis adentros: "Sin duda esta horrible alimaña ha sido arrojada aquí por el tempestuoso viento que ruge afuera; ahora mismo, dentro de breves minutos, va a emprender el vuelo para nunca más turbar mis sueño". Pero nada, me había engañado. La fatídica ave continuó en el mismo sitio, imperturbable, mirándome de hito en hito, como si se recreara en mi secreta angustia.

Por fin amaneció, y el primer rayo de luz le hizo huir por la alta claraboya de mi dormitorio; pero a la siguiente noche, con sorprendente puntualidad, volvió a aparecérseme, cuando se extinguía el eco de la última campanada de mi viejo reloj de pared.

Y ahora, asómbrese usted, mi bella amiga, y si puede, descífreme el misterio. Es el caso que insensiblemente -no sé si fue alucinación de mis sentidos o espantable realidad- fui notando una transformación en las facciones del vampiro, y cosa más rara, eran las suyas, encantadora Elvira, las que iba adquiriendo el maldito nictálope. Así su mirada enigmática me hacía pensar en la de usted, cálida, profundamente sugestiva y llena de misteriosas promesas; también sus labios finos y sensuales, que tantas veces presionaron los míos con amante frenesí, los he percibido en la cara del vampiro. Además, algunos de sus movimientos, algunas de sus actitudes despertaban en mi sobreexcitada imaginación el recuerdo de ciertas posturas 
indolentes que adopta usted en sus horas de ocio, y cuando sentía sobre mi frente el suave roce de sus membranosas alas, creía tenerla a usted muy junto a mí, en aquellas noches de dulce embriaguez amorosa, en que sus luengos y profusos cabellos me acariciaban finos y flexibles.

No obstante esto, yo tenía un miedo horroroso. ¿Por qué? No sabría explicármelo. Pero desde el fondo de mi cerebro, como fiera que atisba atentamente la próxima presa, la locura acechaba el instante propicio para apoderarse de mis facultades intelectuales.

Entonces comprendí que era necesario librarme a todo trance de esa obsesión satánica, y formé el propósito de matar al vampiro. En efecto, un día afilé un agudo puñal y lo oculté bajo mi almohada. Con nerviosa impaciencia sentí transcurrir las horas. Por fin le oí posarse sobre mi cabecera, saqué el arma y alzando rápidamente el brazo..."

Durante el curso de mi narración me había entretenido jugueteando con el mango de un cuchillo que servía para cortar las pastas, pero al llegar a esta parte, un impulso homicida sacudió mis nervios. Callé por varios instantes saboreando interiormente, con salvaje alegría, su dolorosa sorpresa al sentirse herida por mi mano. De pronto renació en mí el odio profundo hacia esa mujer que tanto había escarnecido mi amor, y sin poder contenerme, casi instintivamente, quizá sugestionado por la deliciosa blancura de sus incitativas carnes, ganado por un súbito vértigo de destrucción, cogí con violencia el cuchillo y simulé asestarle una puñalada en su opulento seno izquierdo que se agitaba suavemente... pero reflexioné al punto en lo que iba a hacer y me contuve.

Al mismo tiempo rasgó los aires un grito de horror, y al reportarme, a muy corta distancia de mí, vi a Elvira de pie, temblorosa de emoción y mirándome con fijeza como pretendiendo adivinar mis verdaderas intenciones.

Pero yo, haciendo un poderoso esfuerzo, intenté sonreír; luego con tono indiferente, pausado, concluí así... "y con vigoroso empuje le partí el corazón. Y, rara coincidencia, creí escuchar un grito semejante al suyo. Sólo de esta manera pude recobrar mi perdida calma".

En seguida arrojando el arma sobre la mesa, me crucé de brazos tranquilamente. Había triunfado; el beso era mío.

Al estrépito, Corot, saliendo de su ensimismamiento, nos dirigió una picaresca sonrisa, después volvió a inclinar la cabeza y se quedó profundamente dormido.

Esta estética llevada adelante por José Antonio Román, especialmente en un cuento como El beso de Elvira, supone que el fracaso (recuérdese el título de su novela) es una cláusula secreta que solo el escritor confrontado particularmente con sus debilidades reconoce. Con el proceso nosológico o la enfermedad ocurre algo más o menos análogo. Ambas experiencias 
(fracaso y enfermedad) pulsan convenientemente las hebras de la conciencia del límite último. Ni una ni otra son síntomas de declinación, $y$, mucho menos, de claudicación; son, por el contrario, estados que jalonan el quehacer literario, privilegiando impulsos ontológicos. En sus trayectorias intersectadas aparecen, de un lado, la tentación de ese fracaso de cuño ribeyriano, impulso ciego que se desentiende de cualquier posible aceptación o "éxito" ulterior, y, del otro, la reducción o consumación del cuerpo vía la enfermedad, que, paradójicamente, actúa como motor o émbolo de la creatividad o como elemento soliviantador del propósito fantástico.

Si bien en el cuento en mención es Elvira -protagonista y hechura típicamente modernista-, en su calidad de hospedadora -luego revelaré con más pertinencia quién es huésped y quién agente en este relato-, al frente de su hogar y dueña de la charla, quien promete recompensar a uno de sus dos invitados con el más exquisito de sus besos al que conmueva hondamente sus nervios "imaginando la más abracadabrante fantasía", y quien, desde luego, preconiza el sesgo del relato (además de aventurarnos en sus predios), es más bien Corot, el artista-pintor quien, al dar cuenta de su experiencia personal, nos abisma de lleno en el ámbito más interesante y sobrecogedor del mismo: el del daño, la patología o la morbidez.

En busca de la configuración de "La exaltación de la bienaventurada Lidwina", título del cuadro y obra mayor del artista (a juzgar por los críticos de ese entonces), Corot nos involucra de lleno en los terrenos de la Nosología. Pero es especialmente a través de la santa mártir holandesa, patrona de los enfermos nacida en el siglo XIV, que nos detiene en este encumbrado sector de los centones para adentrarse y hacernos partícipe de esta suerte de paradigma literario-nosológico, bisectriz de lo que me animaría a denominar una suerte de literatura infecta, vale decir, empleo de un lenguaje al servicio de una literatura mórbida, neurasténica o de dominio siniestro.

El autor dice:

De una belleza incomparable, pero rebosante de piedad, obtuvo del Señor que hiciera caer sobre sus frescas carnes de virgen las más repugnantes enfermedades. Desde ese instante, condenada a un forzado reposo sobre su miserable camastro, pasó treinta y cinco años en medio de los más crueles dolores, todo su adorable y blanco cuerpo cubierto de purulentas úlceras. (11)

Dios-Lidwina queda erigida así en la dupla favorecedora o propiciadora del desencadenamiento pertinente del mal en la medida en que el primero (Dios) apunta como agente y el segundo (Lidwina) como huésped, determinantes 
ambos, junto con el medio ambiente, de ese ámbito mayor que viene a ser la salud o la sanidad. Lidwina, predispuesta, o si se quiere entregada a la posibilidad real de una pérdida del equilibrio interno (homeostasis), alberga alternativamente tanto a Dios, suprema entidad, como a la enfermedad, prodigada a su vez por el primero de estos. Pero la dualidad no se cierra ahí, pues Lidwina -en un doble juego de corresponsabilidades- alberga y es albergada. El narrador nos dice:

No satisfecha aún su inextinguible sed de sacrificio, suplicó al Eterno en cierta ocasión en que la peste desolaba a Holanda, que fuera ella su primera víctima. Dios escuchó sus votos, y dos pústulas brotaron en su pecho; pero la mártir pidió una tercera, y esta última más horrorosa la comió la nariz y le hizo saltar uno de los ojos, mientras el otro se cerraba para siempre a la luz del día. (11)

En su condición de hospedadora, caracterizada por una alteración de su estado ontológico de salud, Lidwina aporta al fenómeno infeccioso, además de los factores extrínsecos, otros de tipo intrínseco que van afectando metódicamente a la exposición, la susceptibilidad o la respuesta a los agentes, en la producción misma de la enfermedad. Las noxas (conjunción de ambos factores) son asumidas por Lidwina con la naturalidad que estos factores desencadenan, pero especialmente con el ánimo de mortificación o sed de sacrificio (vía el trance físico y espiritual) que la santa-mártir se inflige para alcanzar el "matrimonio" deseado con la divinidad.

El agente, vía la mano de Dios, queda inoculado en Lidwina. Este episodio constituye el primer acercamiento a la enfermedad presente en el relato. Aquí, ésta se opera de manera llamémosle "tradicional" o "natural", en la medida en que queda establecida o definida como lo que es: una entidad opuesta a la salud, cuyo efecto negativo no es otro que la consecuencia natural de una alteración, desequilibrio o desarmonización a cualquier nivel (molecular, corporal, mental, emocional, espiritual, etc). del estado fisiológico y/o morfológico establecidos apriorísticamente como normales, armónicos o equilibrados. Lo interesante viene a ser, en este caso, la pretensión del narrador:

Pues bien [dice él] yo quería trasladarla al lienzo, toda palpitante de vida, pero cubierto de llagas, en el instante mismo en que tendiendo las manos al Señor subía al Cielo aclamada por los coros de ángeles. (11)

Acá se recusa el poder igualatorio de la muerte. Y a su vez, se clausura el discurso completo sobre la enfermedad (la nosología) en la medida en que, como lectores, asistimos, de un lado, a la exposición o muestra de los síntomas (semiología), al descubrimiento y encumbramiento de la enfermedad (etiología) y a la cuasi revelación místico-religiosa, según la cual el agente causa la enfermedad (patogenia o patogenesia). 
Es evidente que Lidwina, en la evolución de su enfermedad, trastoca los períodos consabidos, y es que alcanza a conocer un comienzo, además de un período clínico (con énfasis en las complicaciones y metástasis), pero en el de la terminación -por curación (sean recaídas o recidivas) o por muerte (agonía, muerte o metagonía)- "degusta" con más fervor el de la agonía, y especialmente el de la metagonía.

Éste era mi pensamiento [sostiene el narrador-pintor]: una noche destemplada, lluviosa, bajo un cielo horriblemente gris; una miserable cueva, muy fría, apenas guarnecida la angosta puerta por toscas cortinas, y adentro, perdida en misteriosa penumbra, acariciada por los pálidos reflejos de una lamparilla exangüe, las flacas manos cruzadas sobre su seno, los descoloridos labios resecos por la fiebre, las pústulas del rostro destilando virus, tendida sobre su lecho la desventurada Lidwina. (1 1)

El concepto de tempus fugit hace rato que ha caído en desuso. Ahora es uno el que puede y/o debe incidir sobre la muerte. La muerte viene enseguida, pero anticipada, y por mano decisiva y nuestra. Entregada al ser divino, la santa se corrompe. Se hace necesario entonces asistir al proceso de deterioro y muerte posterior con el ánimo de ser testigo o capturar dicha progresión. El cotidie morimur no convoca cuando es la muerte la que trata a todos por igual. Por ello, si Dios funciona como agente, Corot también.

Así realizaba el objetivo de mi existencia [sostiene el pintor en otro aparte], así colmaba las aspiraciones de mi espíritu, que era pintar el cuerpo humano, no vigoroso, ágil, pletórico de salud, sino la carne enferma, gangrenada por los vicios, corroída fibra a fibra; el cuerpo con todas sus hediondas lacerías, porque yo detestaba cordialmente los miembros sanos, rebosantes de savia vital, de igual manera que los temperamentos equilibrados de los burgueses. (11)

Acá Corot, hecho a su investidura de narrador-pintor, contrapone a Lidwina -más tarde a Ana (el modelo ideal a deteriorar) con Elvira, la disparadora de la contienda y el paradigma de la belleza que él mismo rechaza, suerte de donna angelicata (prototipo de humanismo; considerada como un ser divino, puro e inteligente, pero a la vez frío y distante).

Entonces, desertor de la sensatez, aunque arguya oportunamente que carece de un soplo de fe religiosa, de ese entusiasmo ingenuo de los hagiógrafos al narrar los milagros de los santos (11)

Corot transita las calles en busca de su paradigma. Y cuando inicia esa búsqueda, empieza propiamente la ceremonia de la caída del tiempo.

$Y$ recorrí los templos [señala] permaneciendo horas enteras envuelto en su dulce penumbra cuando cae la tarde y en los retablos de las 
vírgenes, semi-difusas, adquieren en sus rostros ese vago colorido de cirio pascual y sus cabellos parecen embeberse en la ascendente oscuridad, mientras en sus vidriosas pupilas algún postrer rayo de sol, filtrándose al través de una alta ojiva, viene a morir con trémulas escintilaciones. (11)

Adscrito a una retórica modernista de la enfermedad, en la que se presenta una suerte de venganza de la materia en contra de la cientifización del pensamiento decimonónico, asistimos también a una somatización de la escritura:

Yo procuraba ganar en mi cerebro esas caras ovaladas, de rasgos finísimos, casi espiritualizados, que instintivamente hacían pensar en el martirio; esas manos diáfanas, de dedos largos como pistilos de flores, incoloras, siempre cruzadas sobre el seno; y esos cuerpos magros, nerviosos, casi sin sexo que cubrían las túnicas castas y ondulantes. (11)

La intercurrencia o preexistencia de la enfermedad en Corot es una realidad que debe liberar. Entonces, en un paso casi natural -dualidad contradictoria o bivalencia- de huésped o agente, el pintor-narrador se lanza a las calles a la caza de alguien cuyo status sea el de un ser operado por esta condición de no firmeza o falta de ella. Y es aquí cuando entra Ana:

Una noche en que obsesionado por mi cuadro vagaba a deshoras por la ciudad, casi al entrar en mi casa, un brazo descarnado y tembloroso, surgido de la oscuridad de una puerta, me detuvo y al mismo tiempo una voz femenina, casi enfermiza, imploró mi caridad. Nerviosamente la cogí por el puño y arrastrándola conmigo la llevé al cercano farol. Entonces pude verle el rostro; era una mujer, muy joven todavía, una de esas criaturas descarriadas que principiando por la mendicidad pronto terminan en la prostitución. (11)

Es claro entonces que Corot, cual agente, discierne de Ana una serie de entidades clínico-semiológicas, identificables y subyugadoras. De manera empírica, el artista plástico reconoce en Ana una distancia con Lidwina, distancia que, luego, vía la deliberada entronización de su condición de agente, alterará ostensiblemente. Corot se erige primero en huésped, luego en agente. Ella, modelo a seguir para el anhelado retrato de Lidwina, cede al asedio del agente, y es que el pintor-narrador explica los móviles de su rapto inicial; los posteriores, los ocultos -de seguro imaginados e incipientes mas no liberados-, surgirán luego, cuando la enemistad entre la concreción del cuadro y el deterioro evidente de la santa resulte a todas luces inarmónico.

Hay una adaptación primera y grata al espacio general y de trabajo, que es la casa. Allí la causa morbífica, si consideramos (aunque debiéramos hacerlo) a ese ámbito como huésped o soliviantador inicial del mal, dispara 
las escenas más inquietantes y se erige en el dominio en el cual la fiebre de inspiración (paroxismo del creador) se revela rutilante y malévolo:

Al día siguiente, muy de mañana, [...] comencé a trabajar. La cosa marchaba a las mil maravillas, y al dejar los pinceles, terminada la tarea, pude lanzar una exclamación de alegría. El conjunto era seductor. La santa aparecía adorable en su actitud yacente, semidesnuda, mostrando su casto vientre de un rosa pálido, aplanado, y cuya curva ideal ascendía a perderse en el tórax muy saliente, dejando percibir, acusadas distintamente bajo la descolorida piel, las costillas, como si los estertores de la muerte quisieran hacerle estallar el pecho; el seno izquierdo roído por una horrible pústula que se extendía hasta el nacimiento del cuello. Un pie descarnado, con extraño color de marfil, se asomaba por debajo de los cobertores. No podía quejarme. (11-12)

La casa, entonces, y especialmente el taller, constituyen una clara invitación a la adaptación. La reacción viva local y general no se desentiende de sus propósitos hasta el instante mismo en que Corot se da de bruces contra la dificultad mayor: el rostro de Ana. En este punto, la casa-huésped, que también oficia de agente, empieza a reducirse hasta ceder su relevancia y trascendencia al mismo Corot, cuyo sentimiento de pesar, derivado de la imposibilidad emergente, se revela en los términos siguientes:

¿Cómo pintar con exactitud impresionadora un rostro así? Luego Ana tenía una tez hechicera de la que se desprendían efluvios de bondad y ternura. Yo no podía avanzar más. Sus ojos sugestivos, de mirada cálida, apasionada, semi velados por sus larguísimas pestañas de oro, me retenían en el asiento, inmóvil, completamente fascinado. Y era que poco a poco su aire de ingenuidad y su dulce pasivismo a todos mis caprichos de artista, violentada por el ardor de la composición, habían cultivado mi voluntad y concluido por apoderarse de mi ánimo. (12)

La doble faceta de la relación amorosa aparece en escena cuando el pintor, aliviado inicialmente su espíritu por el hallazgo de una figura a retratar, empieza a ser rodeado o abordado por la figura de la amada como enemiga.

Estaba perdido [señala], mientras me enamorara [de] esa mujer no podía continuar mi cuadro. (12)

Esta imposibilidad constituye el elemento-eje con y sobre el que se revela -en su auténtico y oscuro resplandor - la dualidad retroalimentadora o consumidora del binomio huésped-agente.

Por último, con el ánimo de mostrar a José Antonio Román en todas sus variantes y preocupaciones estilísticas como escritor, presento a 
continuación un texto inusual de nuestro autor. El fantasma de la niebla ${ }^{55}$, fechado en 1908, en lquique, se aparta de sus búsquedas iniciales, enmarcadas en referentes históricos o recreaciones míticas, o en las descripciones sólitas del mar y/o sus bañistas, como en el cuento Marina ${ }^{56}$, especialmente cuando señala:

Más allá, pasados los límites espumosos, el mar se dilata majestuoso y policromático; al comienzo es incoloro, después gris; adentro ostenta un verde manzana y un verdinegro; y en el confín, cerca del horizonte, deslumbra con su variada coloración: azul, azul claro, violeta, azul prusia y concluye con un circular borde lapislázuli, donde se conectan lo finito con lo infinito. (203)

Esta vez el autor nos ubica ante la presencia de un elemento natural -la espesura sobrecogedora y misteriosa de la niebla- como un personaje central. Con un exotismo paradigmático en él, pero sin la sobrecarga de sus textos iniciales y, por lo tanto, con un control más prudente en el ejercicio de la prosa, el autor corporiza al fenómeno natural, dotándolo de anuncios y premoniciones, como si de un alma errante se tratase. Contrario a lo que una persecución sólita de los predios del espíritu tenebroso podría o tendría que ofrecer, Román hace que su personaje no se entregue al clima sobrecogedor, usualmente transitado, sino que por el contrario enrumbe hacia climas soleados y benignos. Pienso entonces que en este cuento el apartamiento de los predios transitados inicialmente por nuestro autor -horror, morbidez, espíritu tanáticoconstituyen la confirmación de un "desarrobamiento" de todos esos ejes o líneas argumentativas en aras de otras inquisiciones, de nuevas consideraciones. Con el advenimiento de un nuevo siglo, el ámbito siniestro en Román da la impresión de replegarse, de aquietarse, para dar paso a otras facturas.

Resulta sintomático además que el autor ubique el desarrollo de la acción en un ámbito ajeno al de sus preocupaciones iniciales. Ya no estamos en países del Oriente Medio, a los que Román siempre le profesó una admiración especial, admiración no solo literaria sino también literal -su libro de viajes Sensaciones de Oriente es una prueba manifiesta de ello-, sino que esta vez se trata de Inglaterra, y específicamente de su capital, Londres.

Indudablemente me aproximo a Hyde Park, según mis cálculos y el tiempo que ha durado mi peregrinación [señala el protagonista del relato]

No obstante, lo más interesante del mismo está dado por las referencias explícitas a escritores foráneos que conforman parte importante del canon

${ }^{55}$ En: Voces del Arte. Almanaque Literario Ilustrado, Año I, edición correspondiente a 1909.

${ }^{56}$ En: El Perú Artístico, Año I, n 17, correspondiente al $1^{\circ}$ de marzo de 1894. 
de un interesado en la materia literaria de lo fantástico, y especialmente del horror. Ahí están Coleridge, Scott y Poe ejerciendo su imperio de lúcido descenso a la ciénaga del ser.

Desde entonces le llamo el fantasma de las nieblas [confiesa el narrador] el que vierte el filtro del insoportable hastío en los espíritus nómades. Es para mí el resumen y compendio de todos los ocultos dolores, de todos los pesares, de los frustrados proyectos de ventura, de los ensueños abortados y de los goces interrumpidos por el prosaísmo de la vida.

\section{El fantasma de la niebla}

Durante las tardes nebulosas de Londres, en medio de ese silencioso discurrir de gentes, mi alma tiene incógnitos terrores y me parece contemplar un mundo de fantasmas o asistir a un espectáculo macabro imaginado por la calenturienta y diabólica fantasía de Edgardo Poe.

Y no obstante mi horror a la niebla, un poderoso e irresistible deseo excita mis nervios; salgo a la calle y empiezo a vagar sin rumbo fijo temeroso de extraviarme, de que un carro o una caballería me atropellen. Esa sensación indefinible, opresora e irritante de aislamiento que envuelve sutilmente al transeúnte, ese pavor de ocultos peligros, de emboscadas sin cuento que uno se forja al percibir el rumor apagado, tenuísimo, del trajinar cotidiano de la multitud, me producen la embriaguez angustiosa, funambulesca y enloquecedora del opio o del haschis de los orientales. Comienzo por perder la noción de las distancias, de los lugares y hasta de mí mismo, pues no acierto a discernir si navego por mares de ensueños, de grises nieblas septentrionales, o si camino por las vías de una populosa metrópoli. Ni los edificios de piedra, monótonos y altos, que bordean los squares, ni la perspectiva de las interminables hileras de árboles que forman las amplias avenidas, nada columbran mis ojos. Londres se esfuma, se desvanece en la masa oscura de la neblina. A dónde voy? No lo sé. Hace muchas horas que ando a la ventura. Me figuro que debo de estar cerca de un parque, pues una mancha verdinegra resalta sobre el fondo ceniciento de las brumas, algo así como una arboleda cercana que abarca todo mi horizonte visual. Indudablemente me aproximo a Hyde Park, según mis cálculos y el tiempo que ha durado mi peregrinación.

Ahora no dudo ya, porque discurro por un sendero y oigo el entrechocar de las hojas de los árboles sacudidos por las ráfagas del viento. Acabo de tropezar con un banco de hierro forjado y me siento a descansar en él.

Entre tanto la niebla se señorea de la vasta soledad del parque. A lo lejos suenan bocinas y pitan silbatos de fábricas. En la bruma espesa y húmeda flotan sus ecos insistentes y debilitados por la distancia, simulando los lúgubres gemidos de un animal moribundo. De vez en cuando se incendia un jirón de niebla: ha pasado por ahí un tranvía con su roja linterna. 
De súbito, como evocación de un mago, noto que una sombra se alza calladamente en el extremo opuesto del banco que ocupo. Mi asombro no tiene límites al cerciorarme de que alguien está ahí. Y sin embargo, puedo afirmar que no había alma viviente cuando yo llegué. Intento ver el rostro de mi desconocido compañero. Es inútil, porque no percibo cosa alguna a dos varas de mis ojos. Entonces me escurro lentamente en dirección al sitio en que se divisa ese extraño ser. Apenas avanzo un metro, una fuerza sobrenatural me detiene. Conozco que no puedo ir más allá y experimento esa rara sensación del que, presa de una pesadilla, sabe que rueda a un abismo, y no obstante la inminencia del peligro lucha en vano contra la poderosa inercia de sus miembros. Se apodera de mí un miedo infantil, como si en torno mío rondase una procesión de espectros.

Hago un esfuerzo de voluntad para reportarme. Me digo a mí mismo que ese temor es quimérico, engendro de mis nervios fatigados por una larga caminata; porque sólo se trata de un excéntrico paseante que ama como yo la solemne quietud de los parques en la tardes nebulosas.

Hasta ese momento no sé cuál es su sexo, pero se me figura que contemplo a una mujer. Su actitud recogida, la gentileza de sus formas y un algo de gracioso y seductor que vislumbro en su silueta que recatan las nieblas, me hacen pensar en ello.

Ciertamente, es una mujer, porque percibo una mano fina, flexible, larga, extremadamente pálida y encorvada como el ala de una paloma, que parece esquiciar un gesto simbólico. Después noto el revuelo de una saya o de los pliegues de una flotante manga, pero todo impreciso, fugitivo y diáfano como una nube.

Las brumas de esta ciudad ejercen sobre los sentidos una posesión malsana que predispone a las más imprevistas y abominables fantasías. Hay un oculto sortilegio en esta humedad que flota disuelta en una atmósfera de ensueño, en los paisajes grises y monótonos de esta ciudad antigua que baña el Támesis color de estaño, movido y removido por los barcos que van a ultramar o vienen de las comarcas de Asia, de los puertos de oro de la India mística y sensual.

Esta visión transparente, velada en las gasas de la bruma, me atrae con mágico horror y despierta en mí una curiosidad morbosa en la que experimento un placer inquieto y doloroso.

Casi me atrevo a decir que conozco desde mucho tiempo atrás a este fantasma. Le he visto otras veces nostálgico e interrogador aparecérseme en los mares de Holanda o en las nieblas de Bélgica. Recuerdo aquella excursión a la isla de Marken, cuando caía la tarde y una lenta neblina, como fino polvo de agua, empezó a difundirse en el ambiente. De pronto, en la popa de la nave que me conducía, vi surgir recatada y misteriosa esta aparición. Fue un brevísimo instante, pues al mostrarse súbitamente la luna se desvaneció ante el límpido fulgor de sus rayos. 
En otra ocasión, cruzando los canales de Brujas durante una medianoche de invierno, creí divisarle al revolver yo una esquina. Pareció bosquejarse un momento en la medrosa claridad que despedían las lámparas de una cercana hornacina. Después, la brisa agitó los cendales que cubrían la imagen del Crucificado, y no supe discernir lo que aquello fue en realidad.

Desde entonces le llamo el fantasma de las nieblas, el que vierte el filtro del insoportable hastío en los espíritus nómades. Es para mí el resumen y compendio de todos los ocultos dolores, de todos los pesares de los frustrados proyectos de ventura, de los ensueños abortados y de los goces interrumpidos por el prosaísmo de la vida.

Mientras cavilo así cobro ánimo y dominando mi espanto, avanzo el cuerpo y extiendo mi mano irreverente para tocarle el hombro; pero me pasma el suceso prodigioso de que me cercioro: ahí no hay nada, absolutamente nada, porque mis dedos se mueven en el vacío. En ese mismo instante, como el clangor guerrero se desbordan las huestes vencidas, las nieblas clarean y los rayos de un sol triunfador doran las copas de los árboles e iluminan el vasto recinto del parque.

$Y$ me retiro de aquel sitio confuso, meditabundo y presa de extrañas aprehensiones alimentadas por reminiscencias de lecturas de Coleridge, Walter Scout [sic] y Poe. Pero de todos modos, producto de mi fantasía o fantasma habitador de villas antiguas, esa visión de misterio se me imagina que es el alma de la niebla o el espíritu de amores muertos. Tal vez sea el ánima de una linajuda Lady que recorre con saudades los parajes en que amó, o la sombra doliente del Londres medioeval que ensangrentó la sañuda guerra civil de las Dos Rosas.

Quizás por eso emigro de los países nebulosos y voy en pos de las cálidas comarcas, de los desiertos de ardientes arenas y de los horizontes azules que recortan los montes de cimas luminosas, donde no prevalece sobre mí el encantamiento de mis pasiones extinguidas, muertas, lejanas ya como la primavera del amor, donde ahuyento el recuerdo de esta mascarada humana, triste feria de apetitos o de vanidades...! 


\section{REFERENCIAS BIBLIOGRÁFICAS}

ARRIOLA GRANDE, Maurilio. Diccionario Literario del Perú. Comercial y Artes Gráficas, S. A. Barcelona: 1968.

CEJADOR Y FRAUCA, Julio. Historia de la lengua y literatura castellana 19151922, comprendidos los autores hispano-americanos. Madrid: Revista de Archivos, Bibliotecas y Museos, 1929, tomo XII.

ESCOBAR, Alberto. La narración en el Perú. Estudio preliminar, antología y notas. Lima: Editorial Juan Mejía Baca, 1960.

GONZÁLEZ VIGIL, Ricardo. El cuento peruano hasta 1919. Lima: Ediciones Copé, Lima: 1992

MORA, Gabriela. Clemente Palma en su versión decadente y gótica. Instituto de Estudios Peruanos (IEP), 2000.

MOSTAJO, Francisco. Francisco Mostajo. Antología de su Obra. Arequipa: Cervecería del Sur, 2002

NÚÑEZ, Estuardo. La literatura peruana en el siglo XX. Lima, 1963. México: Editorial Pomaca, S.A. de C.V., 1965

OVIEDO, José Miguel. Historia de la literatura hispanoamericana. Tomo 3. Postmodernismo, Vanguardia, Regionalismo. Madrid: Alianza Editorial, S.A., 2001.

PALMA, Clemente. Cuentos malévolos. Barcelona: Imp. Salvat y Cía., 1904

Cuentos malévolos. París: Librería Paul Ollendorff, 1912. Filosofía y Arte Lima: s/n, 1897.

ROMÁN, José Antonio. Almas inquietas; novelas. Barcelona: J. Franci, 1914 Fracaso: novela peruana. Barcelona: Gasso Hermanos, 1919 Hojas de mi álbum. R. Velasco, imp. Madrid: 1903 Ibsen y su teatro: estudio crítico. Lima: Libr., Impr. Y Encuadernación Gil, 1895 La pintura japonesa. Lima: s/n, 1894.

La propiedad literaria y artística. Santiago de Chile: Imp. Y Encuadernación del Comercio, 1906

Sensaciones de oriente. Gassó Hermanos Editores, s.a., 1910.

ROMERO DE VALLE, Emilia Diccionario manual de literatura peruana y materias afines. Talleres de la Imprenta de la Universidad Nacional, 1966.

SÁNCHEZ, Luis Alberto. La literatura peruana. Derrotero para una Historia Cultural del Perú. P. L. Villanueva Editor, 1966, tomos III y IV. 
SCHULMAN, Ivan A. Nuevos asedios al Modernismo. Madrid: Taurus Ediciones, 1987.

TORO MONTALVO, César. Historia de la literatura peruana.. Lima: A.F.A., 1996, Tomo VII Modernismo.

VARALLANOS, Adalberto. Permanencia. Cuentos, poemas, crítica y otros escritos. Ediciones Andimar. Buenos Aires: 1968.

ZAVALETA, Carlos Eduardo y CHIRI JAIME, Sandro. El cuento peruano en San Marcos. Lima: Fondo Editorial de la Universidad Nacional Mayor de San Marcos, 2003.

Gonzalo Portals Zubiate pertenece a la Red de Investigadores Autónomos (R.I.A). Ganador del Premio Copé de Poesía 1993 y tercer lugar del Premio Copé de Narrativa 1992. Ha publicado diversos libros de creación literaria y ensayos sobre literatura fantástica y horror. Dentro de la investigación, en el año 2007, publicó La estirpe del ensueño, antología de narrativa fantástica peruana. También destaca su antología de poesía siniestra peruana, Urge púrpura la niebla, que explora el sentimiento poético del horror, lo macabro, y lo siniestro en la poesía peruana desde el Romanticismo hasta el siglo XXI. Es el organizador de los Congresos Internacionales de Literatura Fantástica.

gonzalo.portals@gmail.com 